Supporting Information

\title{
Liquid Properties of Ionic Liquids Based on Phosphonium Cations with (Alkylthio)alkyl Groups
}

\author{
je-2019-00033e \\ Hideaki Shirota, ${ }^{*}$ Kotaro Takahashi, Masatoshi Ando, Shohei Kakinuma
}

Department of Chemistry, Chiba University, 1-33 Yayoi, Inage-ku, Chiba 263-8522, Japan

shirota@faculty.chiba-u.jp 


\section{Details of Synthesis Procedures of Ionic Liquids.}

\subsection{Triethyl[(methylthio)methyl]phosphonium bis(trifluoromethylsulfonyl)amide, [P222(III)][NTf 2$]$.}

Chloromethyl methyl sulfide $(0.92 \mathrm{~mL}, 11 \mathrm{mmol})$ was added to triethylphosphine toluene solution $(20 \%, 6.7$ $\mathrm{mL}, 9.1 \mathrm{mmol}$ ) at nitrogen atmosphere in a flask equipped with a reflux condenser and magnetic stirrer. The solution was stirred, and then heated to ca. $120{ }^{\circ} \mathrm{C}$ in an oil bath for 20 hours while stirring. After that, the flask was allowed to cool to room temperature. The toluene layer was removed, and the residual solid was washed with toluene several times. The solid was then dissolved by acetonitrile, and the solution was evaporated. The solid was dried in vacuo at ambient temperature for approximately 2 hours. The obtained solid ([P $\left.\left.\mathrm{P}_{22(1 \mathrm{S1})}\right] \mathrm{Cl}, 1.8 \mathrm{~g}, 8.5 \mathrm{mmol}\right)$ was successively dissolved in water, and aqueous solution of lithium bis(trifluoromethylsulfonyl)amide $(2.9 \mathrm{~g}, 10 \mathrm{mmol})$ was added. After the mixture was stirred at room temperature for 1.5 hours, it was settled. The ionic liquid phase was washed with water five times and then hexane five times. The obtained ionic liquid was dried in vacuo at $40{ }^{\circ} \mathrm{C}$ for more than 2 days. The yield was $74 \%$ (3.1 g). $\quad{ }^{1} \mathrm{H}-\mathrm{NMR}$ (400 MHz, $d_{6}$-DMSO): $\delta=1.16$ (tt, $J=7.6$ and $9.2 \mathrm{~Hz}, \mathrm{PCH}_{2} \mathrm{CH}_{3}, 9 \mathrm{H}$ ), $\delta=2.29$ (m, $\mathrm{PCH}_{2} \mathrm{CH}_{3}$ and $\left.\mathrm{PCH}_{2} \mathrm{SCH}_{3}, 9 \mathrm{H}\right), \delta=3.57$ (d, $J=9.6 \mathrm{~Hz}, \mathrm{PCH}_{2} \mathrm{SCH}_{3}, 2 \mathrm{H}$ ). Elemental analysis: $\mathrm{C}_{10} \mathrm{H}_{20} \mathrm{~F}_{6} \mathrm{NO}_{4} \mathrm{PS}_{3}$ : Calcd. C 26.14, H 4.39, N 3.05. Found C 26.22, H 4.39, N 3.09.

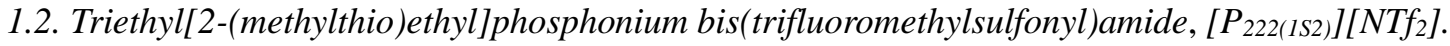

2-Chloroethyl methyl sulfide was distilled before use. The distilled 2-chloroethyl methyl sulfide (1.7 mL, 17 mmol) was added to triethylphosphine toluene solution $(20 \%, 10 \mathrm{~mL}, 14 \mathrm{mmol})$ at nitrogen atmosphere in a flask equipped with a reflux condenser and magnetic stirrer. The solution was stirred, and then heated to ca. $120^{\circ} \mathrm{C}$ in an oil bath for 19 hours while stirring. After that, the flask was allowed to cool to room temperature. The toluene layer was removed, and the residual solid was washed with toluene several times. The solid was then dissolved by acetonitrile, and the solution was evaporated. The residual solid was dried in vacuo at ambient temperature for approximately 14 hours. The obtained solid $\left(\left[\mathrm{P}_{222(1 \mathrm{~S} 2)}\right] \mathrm{Cl}, 2.1 \mathrm{~g}, 9.3 \mathrm{mmol}\right)$ was then successively dissolved in water, and aqueous solution of lithium bis(trifluoromethylsulfonyl)amide (3.3 g, 11 mmol) was added. After the mixture was stirred at room temperature for 4 hours, it was settled. The ionic liquid layer was dissolved in dichloromethane and washed with water five times. The solution was evaporated and then washed with hexane five times. The obtained ionic liquid was dried in vacuo at $40{ }^{\circ} \mathrm{C}$ for more than 2 days. The yield was 66\% (4.2 g). ${ }^{1} \mathrm{H}-\mathrm{NMR}\left(400 \mathrm{MHz}, \mathrm{CDCl}_{3}\right): \delta=1.28$ (tt, $J=7.7$ and $9.2 \mathrm{~Hz}$, $\mathrm{PCH}_{2} \mathrm{CH}_{3}, 9 \mathrm{H}$ ), $\delta=2.18\left(\mathrm{~s}, \mathrm{PCH}_{2} \mathrm{CH}_{2} \mathrm{SCH}_{3}, 3 \mathrm{H}\right.$ ), $\delta=2.27$ (qq, $J=7.7$ and $12.7 \mathrm{~Hz}, 6 \mathrm{H}$ ), $\delta=2.49$ (tt, $J=7.3$ and $12.5 \mathrm{~Hz}, \mathrm{PCH}_{2} \mathrm{CH}_{2} \mathrm{~S}, 2 \mathrm{H}$ ), $\delta=2.76\left(\mathrm{tt}, J=7.5\right.$ and $13.8 \mathrm{~Hz}, \mathrm{PCH}_{2} \mathrm{CH}_{2} \mathrm{~S}, 2 \mathrm{H}$ ). Elemental analysis: $\mathrm{C}_{11} \mathrm{H}_{22} \mathrm{~F}_{6} \mathrm{NO}_{4} \mathrm{PS}_{3}$ : Calcd. C 27.91, H 4.68, N 3.05. Found C 27.68, H 4.55, N 2.71.

\subsection{Triethyl[2-(ethylthio)ethyl]phosphonium bis(trifluoromethylsulfonyl)amide, [ $\left.P_{222(2 S 2)}\right]\left[N T f_{2}\right]$.}

2-Chloroethyl ethyl sulfide (3.0 mL, $26 \mathrm{mmol})$ was added to triethylphosphine toluene solution $(20 \%, 15 \mathrm{~mL}$, $20 \mathrm{mmol}$ ) at nitrogen atmosphere in a flask equipped with a reflux condenser and magnetic stirrer. The 
solution was stirred, and then heated to ca. $120{ }^{\circ} \mathrm{C}$ in an oil bath for 18 hours while stirring. After that, the flask was allowed to cool to room temperature. The toluene layer was removed, and the residual solid was washed with toluene several times. The solid was then dissolved by acetonitrile, and the solution was evaporated. The solid was dried in vacuo at ambient temperature for approximately 2 hours. The obtained solid $\left(\left[\mathrm{P}_{222(2 \mathrm{~S} 2)}\right] \mathrm{Cl}, 4.7 \mathrm{~g}, 19 \mathrm{mmol}\right)$ was then successively dissolved in water, and aqueous solution of lithium bis(trifluoromethylsulfonyl)amide $(7.1 \mathrm{~g}, 25 \mathrm{mmol})$ was added. After the mixture was stirred at room temperature for 1.5 hours, it was settled. The ionic liquid phase was washed with water five times and then hexane five times. The obtained ionic liquid was then dried in vacuo at $40{ }^{\circ} \mathrm{C}$ for more than 2 days. The yield was $83 \%$ (8.1 g). $\quad{ }^{1} \mathrm{H}-\mathrm{NMR}\left(400 \mathrm{MHz}, \mathrm{CD}_{3} \mathrm{OD}\right): \delta=1.23\left(\mathrm{~m}, \mathrm{PCH}_{2} \mathrm{CH}_{3}\right.$ and $\left.\mathrm{SCH}_{2} \mathrm{CH}_{3}, 12 \mathrm{H}\right), \delta=2.31$ $\left(\mathrm{dq}, J=7.7\right.$ and $\left.12.9 \mathrm{~Hz}, \mathrm{PCH}_{2} \mathrm{CH}_{3}, 6 \mathrm{H}\right), \delta=2.55\left(\mathrm{dt}, J=7.5\right.$ and $\left.13.1 \mathrm{~Hz}, \mathrm{PCH}_{2} \mathrm{CH}_{2} \mathrm{~S}, 2 \mathrm{H}\right), \delta=2.66(\mathrm{q}, J=$ $\left.7.4 \mathrm{~Hz}, \mathrm{SCH}_{2} \mathrm{CH}_{3}, 2 \mathrm{H}\right), \delta=2.82\left(\mathrm{~m}, \mathrm{PCH}_{2} \mathrm{CH}_{2} \mathrm{~S}, 2 \mathrm{H}\right)$. Elemental analysis: $\mathrm{C}_{12} \mathrm{H}_{24} \mathrm{~F}_{6} \mathrm{NO}_{4} \mathrm{PS}_{3}$ : Calcd. C 29.57, H 4.96, N 2.87. Found C 29.34, H 4.86, N 2.57.

\subsection{Tributyl[(methylthio)methyl]phosphonium bis(trifluoromethylsulfonyl)amide, [P 444(ISI)][NTf 2$]$.}

Chloromethyl methyl sulfide $(3.1 \mathrm{~mL}, 36 \mathrm{mmol})$ was added to tributylphosphine $(7.5 \mathrm{~mL}, 30 \mathrm{mmol})$ at nitrogen atmosphere in a flask equipped with a reflux condenser and magnetic stirrer. The solution was stirred, and then heated to ca. $120{ }^{\circ} \mathrm{C}$ in an oil bath for 19 hours while stirring. After that, the flask was allowed to cool to room temperature. The solid was washed with toluene-hexane mixture several times. The solid was then dissolved by acetonitrile, and the solution was evaporated. The residual solid was dried in vacuo at $40{ }^{\circ} \mathrm{C}$ for approximately 3 hours. The obtained solid ([P $\left.\left.\mathrm{P}_{444(1 \mathrm{~S} 1)}\right] \mathrm{Cl}, 8.9 \mathrm{~g}, 30 \mathrm{mmol}\right)$ was then successively dissolved in water, and aqueous solution of lithium bis(trifluoromethylsulfonyl)amide (10 g, $37 \mathrm{mmol})$ was added. After the mixture was stirred at room temperature for 1.5 hours, it was settled. The ionic liquid phase was washed with water five times, then diethyl ether-hexane mixture five times, and diethyl ether-ethanol mixture five times. The obtained ionic liquid was dried in vacuo at $40{ }^{\circ} \mathrm{C}$ for more than 2 days. The yield was $72 \%$ (12 g). ${ }^{1} \mathrm{H}-\mathrm{NMR}$ (400 MHz, $d_{6}$-DMSO): $\delta=0.92$ (t, $\left.J=7.2 \mathrm{~Hz}, \mathrm{PCH}_{2} \mathrm{CH}_{2} \mathrm{CH}_{2} \mathrm{CH}_{3}, 9 \mathrm{H}\right), \delta=1.46$ (m, $\left.\mathrm{PCH}_{2} \mathrm{CH}_{2} \mathrm{CH}_{2} \mathrm{CH}_{3}, 12 \mathrm{H}\right), \delta=2.25\left(\mathrm{~m}, \mathrm{PCH}_{2} \mathrm{CH}_{2} \mathrm{CH}_{2} \mathrm{CH}_{3}\right.$ and $\left.\mathrm{PCH}_{2} \mathrm{SCH}_{3}, 9 \mathrm{H}\right), \delta=3.55(\mathrm{~d}, J=9.5 \mathrm{~Hz}$, $\left.\mathrm{PCH}_{2} \mathrm{SCH}_{3}, 2 \mathrm{H}\right)$. Elemental analysis: $\mathrm{C}_{16} \mathrm{H}_{32} \mathrm{~F}_{6} \mathrm{NO}_{4} \mathrm{PS}_{3}$ : Calcd. C 35.35, H 5.93, N 2.58. Found C 35.14, $\mathrm{H}$ 5.76, N 2.57.

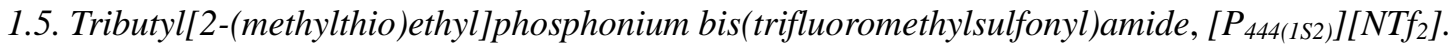

2-Chloroethyl methyl sulfide was distilled before use. The distilled 2-chloroethyl methyl sulfide (1.8 mL, 18 mmol) was added to tributylphosphine $(3.8 \mathrm{~mL}, 15 \mathrm{mmol})$ at nitrogen atmosphere in a flask equipped with a reflux condenser and magnetic stirrer. The solution was stirred, and then heated to ca. $120{ }^{\circ} \mathrm{C}$ in an oil bath for approximately 20 hours while stirring. After that, the flask was allowed to cool to room temperature. The solution was washed with hexane several times. The liquid was then dried in vacuo at ambient temperature for approximately 2 hours. The obtained liquid $\left(\left[\mathrm{P}_{444(1 \mathrm{~S} 2)}\right] \mathrm{Cl}, 4.8 \mathrm{~g}, 15 \mathrm{mmol}\right)$ was successively 
dissolved in water, and aqueous solution of lithium bis(trifluoromethylsulfonyl)amide (5.3 g, $18 \mathrm{mmol})$ was added. After the mixture was stirred at room temperature for 1.5 hours, it was settled. The ionic liquid phase was washed with water five times and then hexane five times. The obtained ionic liquid was dried in vacuo at $40{ }^{\circ} \mathrm{C}$ for more than 2 days. The yield was $98 \%(8.2 \mathrm{~g})$. ${ }^{1} \mathrm{H}-\mathrm{NMR}\left(400 \mathrm{MHz}, \mathrm{CD}_{3} \mathrm{OD}\right): \delta=1.00$ (t, $\left.J=7.0 \mathrm{~Hz}, \mathrm{PCH}_{2} \mathrm{CH}_{2} \mathrm{CH}_{2} \mathrm{CH}_{3}, 9 \mathrm{H}\right), \delta=1.54\left(\mathrm{~m}, \mathrm{PCH}_{2} \mathrm{CH}_{2} \mathrm{CH}_{2} \mathrm{CH}_{3}, 12 \mathrm{H}\right), \delta=2.22\left(\mathrm{~m}, \mathrm{PCH}_{2} \mathrm{CH}_{2} \mathrm{CH}_{2} \mathrm{CH}_{3}\right.$ and $\left.\mathrm{SCH}_{3}, 9 \mathrm{H}\right), \delta=2.56\left(\mathrm{~m}, \mathrm{PCH}_{2} \mathrm{CH}_{2} \mathrm{~S}, 2 \mathrm{H}\right), \delta=2.78\left(\mathrm{~m}, \mathrm{PCH}_{2} \mathrm{CH}_{2} \mathrm{~S}, 2 \mathrm{H}\right)$. Elemental analysis: $\mathrm{C}_{17} \mathrm{H}_{34} \mathrm{~F}_{6} \mathrm{NO}_{4} \mathrm{PS}_{3}$ : Calcd. C 36.62, H 6.15, N 2.51. Found C 36.53, H 6.06, N 2.36.

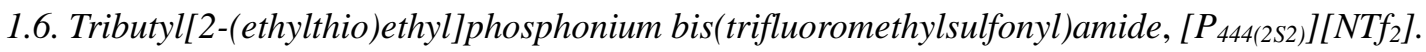

2-Chloroethyl ethyl sulfide (1.9 mL, $16 \mathrm{mmol})$ was added to tributylphosphine $(3.1 \mathrm{~mL}, 12 \mathrm{mmol})$ at nitrogen atmosphere in a flask equipped with a reflux condenser and magnetic stirrer. The solution was stirred, and then heated to ca. $120{ }^{\circ} \mathrm{C}$ in an oil bath for 42 hours while stirring. After that, the flask was allowed to cool to room temperature. The obtained liquid was washed with hexane several times, and then evaporated. The liquid was dried in vacuo at $40{ }^{\circ} \mathrm{C}$ for approximately 21 hours. The obtained liquid $\left(\left[\mathrm{P}_{444(2 \mathrm{~S} 2)}\right] \mathrm{Cl}, 3.4 \mathrm{~g}, 10\right.$ mmol) was then successively dissolved in 1:1 (v/v) mixture of water and acetone. Lithium bis(trifluoromethylsulfonyl)amide (3.6 g, $12 \mathrm{mmol})$ was also dissolved in 1:1 (v/v) mixture of water and acetone, and the solutions were mixed. After the mixture was stirred at room temperature for 14 hours, the solution was evaporated. The obtained liquid was dissolved in dichloromethane and washed with water five times. The solution was evaporated and then washed with hexane five times. The obtained ionic liquid was then dried in vacuo at $40{ }^{\circ} \mathrm{C}$ for more than 2 days. The yield was $80 \%$ (4.9 g). ${ }^{1} \mathrm{H}-\mathrm{NMR}(400 \mathrm{MHz}$, $\left.\mathrm{CD}_{3} \mathrm{OD}\right): \delta=1.00\left(\mathrm{t}, J=7.1 \mathrm{~Hz}, \mathrm{PCH}_{2} \mathrm{CH}_{2} \mathrm{CH}_{2} \mathrm{CH}_{3}, 9 \mathrm{H}\right), \delta=1.28\left(\mathrm{t}, J=7.4 \mathrm{~Hz}, \mathrm{PCH}_{2} \mathrm{CH}_{2} \mathrm{SCH}_{2} \mathrm{CH}_{3}, 3 \mathrm{H}\right), \delta=$ $1.54\left(\mathrm{~m}, \mathrm{PCH}_{2} \mathrm{CH}_{2} \mathrm{CH}_{2} \mathrm{CH}_{3}, 12 \mathrm{H}\right), \delta=2.26\left(\mathrm{~m}, \mathrm{PCH}_{2} \mathrm{CH}_{2} \mathrm{CH}_{2} \mathrm{CH}_{3}, 6 \mathrm{H}\right), \delta=2.64\left(\mathrm{~m}, \mathrm{PCH}_{2} \mathrm{CH}_{2} \mathrm{~S}, 2 \mathrm{H}\right), \delta=$ 2.65 (q, $\left.J=7.5, \mathrm{SCH}_{2} \mathrm{CH}_{3}, 2 \mathrm{H}\right), \delta=2.82$ (m, $\mathrm{PCH}_{2} \mathrm{CH}_{2} \mathrm{~S}, 2 \mathrm{H}$ ). Elemental analysis: $\mathrm{C}_{18} \mathrm{H}_{36} \mathrm{~F}_{6} \mathrm{NO}_{4} \mathrm{PS}_{3}$ : Calcd. C 37.82, H 6.35, N 2.45. Found C 37.98, H 6.29, N 2.47.

\subsection{Triethyl[(methylthio)methyl]phosphonium bis(fluorosulfonyl)amide, $\left[\mathrm{P}_{222(I S I)}\right]\left[\mathrm{NF}_{2}\right]$.}

Chloromethyl methyl sulfide $(2.2 \mathrm{~mL}, 26 \mathrm{mmol})$ was added to triethylphosphine toluene solution $(20 \%, 15 \mathrm{~mL}$, $20 \mathrm{mmol}$ ) at nitrogen atmosphere in a flask equipped with a reflux condenser and magnetic stirrer. The solution was stirred, and then heated to ca. $120{ }^{\circ} \mathrm{C}$ in an oil bath for approximately 20 hours while stirring. After that, the flask was allowed to cool to room temperature. The toluene layer was removed, and the residual solid was washed with toluene several times. The solid was then dissolved in acetonitrile, and the solution was evaporated. The solid was dried in vacuo at ambient temperature for approximately 2 hours. The obtained solid ([ $\left.\left.\mathrm{P}_{222(1 \mathrm{~S} 1)}\right] \mathrm{Cl}, 4.3 \mathrm{~g}, 20 \mathrm{mmol}\right)$ was successively dissolved in water, and aqueous solution of lithium bis(fluoromethylsulfonyl)amide $(4.8 \mathrm{~g}, 26 \mathrm{mmol})$ was added. After the mixture was stirred at room temperature for 1.5 hours, it was settled. The ionic liquid phase was washed with water five times and then washed with hexane five times. The resultant ionic liquid and activated carbon were added in acetonitrile, and 
stirred at room temperature overnight. The obtained ionic liquid was then dried in vacuo at $40{ }^{\circ} \mathrm{C}$ for more than 2 days. The yield was 94\% (6.7 g). ${ }^{1} \mathrm{H}-\mathrm{NMR}$ (400 MHz, $d_{6}$-DMSO): $\delta=1.17$ (tt, $J=7.7$ and $18.4 \mathrm{~Hz}$, $\left.\mathrm{PCH}_{2} \mathrm{CH}_{3}, 9 \mathrm{H}\right), \delta=2.29\left(\mathrm{~m}, \mathrm{PCH}_{2} \mathrm{CH}_{3}\right.$ and $\left.\mathrm{PCH}_{2} \mathrm{SCH}_{3}, 9 \mathrm{H}\right), \delta=3.55\left(\mathrm{~d}, J=9.5 \mathrm{~Hz}, \mathrm{PCH}_{2} \mathrm{SCH}_{3}, 2 \mathrm{H}\right)$. Elemental analysis: $\mathrm{C}_{8} \mathrm{H}_{20} \mathrm{~F}_{2} \mathrm{NO}_{4} \mathrm{PS}_{3}$ : Calcd. C 26.74, H 5.61, N 3.90. Found C 26.56, H 5.46, N 3.84.

\subsection{Triethyl[2-(methylthio)ethyl]phosphonium bis(fluorosulfonyl)amide, $\left[\mathrm{P}_{222(I S 2)}\right]\left[\mathrm{NF}_{2}\right]$.}

2-Chloroethyl methyl sulfide was distilled before use. The distilled 2-chloroethyl methyl sulfide (2.5 mL, 25 mmol) was added to triethylphosphine toluene solution $(20 \%, 13 \mathrm{~mL}, 18 \mathrm{mmol})$ at nitrogen atmosphere in a flask equipped with a reflux condenser and magnetic stirrer. The solution was stirred, and then heated to ca. $120{ }^{\circ} \mathrm{C}$ in an oil bath for approximately 15 hours while stirring. After that, the flask was allowed to cool to room temperature. The toluene layer was removed, and the residual solid was washed with toluene several times. The solid was then dissolved by acetonitrile, and the solution was evaporated. The solid was dried in vacuo at ambient temperature for approximately 2 hours. The obtained solid $\left(\left[\mathrm{P}_{222(1 \mathrm{~s} 2)}\right] \mathrm{Cl}, 2.9 \mathrm{~g}, 13 \mathrm{mmol}\right)$ was then successively dissolved in water, and aqueous solution of lithium bis(fluorosulfonyl)amide ( $3.1 \mathrm{~g}, 17$ mmol) was added. After the mixture was stirred at room temperature for 4 hours, it was settled. The ionic liquid layer was dissolved in dichloromethane and washed with water five times. The solution was evaporated and then washed with hexane five times. The resultant ionic liquid and activated carbon were added in acetonitrile, and the solution was stirred at room temperature overnight. After the filtration, the solution was evaporated. The obtained ionic liquid was then dried in vacuo at $40{ }^{\circ} \mathrm{C}$ for more than 2 days. The yield was 70\% (4.2 g). ${ }^{1} \mathrm{H}-\mathrm{NMR}\left(400 \mathrm{MHz}, \mathrm{CD}_{3} \mathrm{OD}\right): \delta=1.27\left(\mathrm{dt}, J=7.5\right.$ and $18.4 \mathrm{~Hz}, \mathrm{PCH}_{2} \mathrm{CH}_{3}$, $9 \mathrm{H}), \delta=2.20\left(\mathrm{~s}, \mathrm{PCH}_{2} \mathrm{CH}_{2} \mathrm{SCH}_{3}, 3 \mathrm{H}\right), \delta=2.27(\mathrm{dq}, J=7.5$ and $13.1 \mathrm{~Hz}, 6 \mathrm{H}), \delta=2.57\left(\mathrm{~m}, \mathrm{PCH}_{2} \mathrm{CH}_{2} \mathrm{~S}\right.$, $2 \mathrm{H}), \delta=2.80\left(\mathrm{~m}, \mathrm{PCH}_{2} \mathrm{CH}_{2} \mathrm{~S}, 2 \mathrm{H}\right)$. Elemental analysis: $\mathrm{C}_{9} \mathrm{H}_{22} \mathrm{~F}_{2} \mathrm{NO}_{4} \mathrm{PS}_{3}$ : Calcd. C 28.95, H 5.94, N 3.75. Found C 28.60, H 5.81, N 3.54.

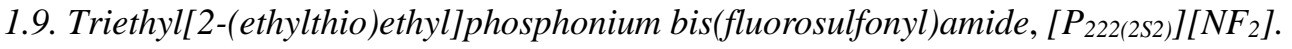

2-Chloroethyl ethyl sulfide $(2.0 \mathrm{~mL}, 17 \mathrm{mmol})$ was added to triethylphosphine toluene solution $(20 \%, 10 \mathrm{~mL}$, $14 \mathrm{mmol}$ ) at nitrogen atmosphere in a flask equipped with a reflux condenser and magnetic stirrer. The solution was stirred, and then heated to ca. $120{ }^{\circ} \mathrm{C}$ in an oil bath for 18 hours while stirring. After that, the flask was allowed to cool to room temperature. The toluene layer was removed, and the residual solid was washed with toluene several times. The solid was then dissolved by acetonitrile, and the solution was evaporated. The solid was dried in vacuo at ambient temperature for approximately 2 hours. The obtained solid $\left(\left[\mathrm{P}_{222(2 \mathrm{~S} 2)}\right] \mathrm{Cl}, 2.6 \mathrm{~g}, 11 \mathrm{mmol}\right)$ was then successively dissolved in water, and aqueous solution of lithium bis(fluorosulfonyl)amide $(2.4 \mathrm{~g}, 13 \mathrm{mmol})$ was added. After the mixture was stirred at room temperature for 1.5 hours, it was settled. The ionic liquid phase was washed with water five times and then hexane five times. The resultant ionic liquid and activated carbon were added in acetonitrile, and stirred at room temperature overnight. After the filtration, the solution was evaporated. The obtained ionic liquid was then dried in 
vacuo at $40{ }^{\circ} \mathrm{C}$ for more than 2 days. The yield was $69 \%(3.6 \mathrm{~g}) . \quad{ }^{1} \mathrm{H}-\mathrm{NMR}\left(400 \mathrm{MHz}, \mathrm{CDCl}_{3}\right): \delta=1.3(\mathrm{tt}, J$ $=7.6$ and $18.8 \mathrm{~Hz}, \mathrm{PCH}_{2} \mathrm{CH}_{3}$ and $\mathrm{t}, J=7.6 \mathrm{~Hz} \mathrm{SCH}_{2} \mathrm{CH}_{3}, 12 \mathrm{H}$ ), $\delta=2.28$ (qq, $J=7.6$ and $12.8 \mathrm{~Hz}, \mathrm{PCH}_{2} \mathrm{CH}_{3}$, $6 \mathrm{H}$ ), $\delta=2.48$ (tt, $J=7.2$ and $12.4 \mathrm{~Hz}, \mathrm{PCH}_{2} \mathrm{CH}_{2} \mathrm{~S}, 2 \mathrm{H}$ ), $\delta=2.64$ (q, $J=7.6 \mathrm{~Hz}, \mathrm{SCH}_{2} \mathrm{CH}_{3}, 2 \mathrm{H}$ ), $\delta=2.82$ (tt, $J$ $=7.6$ and $\left.14.0 \mathrm{~Hz}, \mathrm{PCH}_{2} \mathrm{CH}_{2} \mathrm{~S}, 2 \mathrm{H}\right)$. Elemental analysis: $\mathrm{C}_{10} \mathrm{H}_{24} \mathrm{~F}_{2} \mathrm{NO}_{4} \mathrm{PS}_{3}$ : Calcd. $\mathrm{C}$ 31.00, H 6.24, N 3.62. Found C 30.98, H 6.27, N 3.63.

\subsection{Tributyl[(methylthio)methyl]phosphonium bis(fluorosulfonyl)amide, [P $444(1 \mathrm{II})]\left[\mathrm{NF}_{2}\right]$.}

Chloromethyl methyl sulfide $(2.3 \mathrm{~mL}, 27 \mathrm{mmol})$ was added to tributylphosphine $(5 \mathrm{~mL}, 20 \mathrm{mmol})$ at nitrogen atmosphere in a flask equipped with a reflux condenser and magnetic stirrer. The solution was stirred, and then heated to ca. $110{ }^{\circ} \mathrm{C}$ in an oil bath for 17 hours while stirring. After that, the flask was allowed to cool to room temperature. The solid was dissolved by acetonitrile, and the solution was evaporated. The residual solid was washed with hexane several times, and evaporated. The obtained solid was dried in vacuo at $40{ }^{\circ} \mathrm{C}$ for approximately 20 hours. The precursor, tributyl[(methylthio)methyl]phosphonium chloride $\left(\left[\mathrm{P}_{444(1 \mathrm{~S})}\right)\right] \mathrm{Cl}$, $5.8 \mathrm{~g}, 19 \mathrm{mmol})$ was obtained. The $\left[\mathrm{P}_{444(1 \mathrm{S1})}\right] \mathrm{Cl}(3.0 \mathrm{~g}, 10 \mathrm{mmol})$ was then dissolved in water, and aqueous solution of lithium bis(fluorosulfonyl)amide $(2.4 \mathrm{~g}, 13 \mathrm{mmol}$ ) was added. After the mixture was stirred at room temperature for 1.5 hours, it was settled. The ionic liquid phase was washed with water five times and then hexane five times. The ionic liquid was then dried in vacuo at $40{ }^{\circ} \mathrm{C}$ for more than 2 days. The yield was $87 \%$ (3.9 g). ${ }^{1} \mathrm{H}-\mathrm{NMR}\left(400 \mathrm{MHz}, \mathrm{CDCl}_{3}\right): \delta=0.98$ (t, $\left.J=7.0 \mathrm{~Hz}, \mathrm{PCH}_{2} \mathrm{CH}_{2} \mathrm{CH}_{2} \mathrm{CH}_{3}, 9 \mathrm{H}\right), \delta=1.54(\mathrm{~m}$, $\left.\mathrm{PCH}_{2} \mathrm{CH}_{2} \mathrm{CH}_{2} \mathrm{CH}_{3}, 12 \mathrm{H}\right), \delta=2.21\left(\mathrm{~m}, \mathrm{PCH}_{2} \mathrm{CH}_{2} \mathrm{CH}_{2} \mathrm{CH}_{3}, 6 \mathrm{H}\right), \delta=2.35$ (d, $J=1.4 \mathrm{~Hz}, \mathrm{PCH}_{2} \mathrm{SCH}_{3}, 3 \mathrm{H}$ ), $\delta=$ $3.28\left(\mathrm{~d}, J=9.7 \mathrm{~Hz}, \mathrm{PCH}_{2} \mathrm{SCH}_{3}, 2 \mathrm{H}\right)$. Elemental analysis: $\mathrm{C}_{14} \mathrm{H}_{32} \mathrm{~F}_{2} \mathrm{NO}_{4} \mathrm{PS}_{3}$ : Calcd. C 37.91, H 7.27, N 3.16. Found C 37.70, H 7.15, N 2.94.

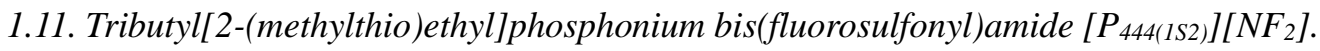

2-Chloroethyl methyl sulfide was distilled before use. The distilled 2-chloroethyl methyl sulfide (2.4 mL, 24 mmol) was added to tributylphosphine $(5.0 \mathrm{~mL}, 20 \mathrm{mmol})$ at nitrogen atmosphere in a flask equipped with a reflux condenser and magnetic stirrer. The solution was stirred, and then heated to ca. $120{ }^{\circ} \mathrm{C}$ in an oil bath for approximately 20 hours while stirring. After that, the flask was allowed to cool to room temperature. The solution was washed with hexane several times. The liquid was then dried in vacuo at ambient temperature for approximately 2 hours. The obtained liquid $\left(\left[\mathrm{P}_{444(1 \mathrm{~S} 2)}\right] \mathrm{Cl}, 6.4 \mathrm{~g}, 20 \mathrm{mmol}\right)$ was successively dissolved in water, and aqueous solution of lithium bis(fluorosulfonyl)amide (4.7 g, $25 \mathrm{mmol})$ was added. After the mixture was stirred at room temperature for 1.5 hours, it was settled. The ionic liquid phase was washed with water five times and then hexane five times. The resultant ionic liquid and activated carbon were added in acetonitrile, and stirred at room temperature overnight. The solution was then filtered and evaporated. The ionic liquid was then dried in vacuo at $40{ }^{\circ} \mathrm{C}$ for more than 2 days. The yield was $91 \%$ ( 8.3 g). ${ }^{1} \mathrm{H}-\mathrm{NMR}\left(400 \mathrm{MHz}, \mathrm{CD}_{3} \mathrm{OD}\right): \delta=1.00$ (t, $\left.J=7.1 \mathrm{~Hz}, \mathrm{PCH}_{2} \mathrm{CH}_{2} \mathrm{CH}_{2} \mathrm{CH}_{3}, 9 \mathrm{H}\right), \delta=1.55$ (m, $\left.\mathrm{PCH}_{2} \mathrm{CH}_{2} \mathrm{CH}_{2} \mathrm{CH}_{3}, 12 \mathrm{H}\right), \delta=2.20\left(\mathrm{~m}, \mathrm{PCH}_{2} \mathrm{CH}_{2} \mathrm{CH}_{2} \mathrm{CH}_{3}\right.$ and $\left.\mathrm{SCH}_{3}, 9 \mathrm{H}\right), \delta=2.55\left(\mathrm{~m}, \mathrm{PCH}_{2} \mathrm{CH}_{2} \mathrm{~S}, 2 \mathrm{H}\right), \delta=$ 
2.81 (m, $\left.\mathrm{PCH}_{2} \mathrm{CH}_{2} \mathrm{~S}, 2 \mathrm{H}\right)$. Elemental analysis: $\mathrm{C}_{15} \mathrm{H}_{34} \mathrm{~F}_{2} \mathrm{NO}_{4} \mathrm{PS}_{3}$ : Calcd. C 39.37, H 7.49, N 3.06. Found C 39.33, H 7.38, N 3.10 .

\subsection{Tributyl[2-(ethylthio)ethyl]phosphonium bis(fluorosulfonyl)amide, $\left[\mathrm{P}_{444(2 S 2)}\right]\left[\mathrm{NF}_{2}\right]$.}

2-Chloroethyl ethyl sulfide ( $2 \mathrm{~mL}, 16 \mathrm{mmol})$ was added to tributylphosphine $(3.2 \mathrm{~mL}, 13 \mathrm{mmol})$ at nitrogen atmosphere in a flask equipped with a reflux condenser and magnetic stirrer. The solution was stirred, and then heated to ca. $140{ }^{\circ} \mathrm{C}$ in an oil bath for 60 hours while stirring. After that, the flask was allowed to cool to room temperature. The liquid was dissolved by acetonitrile, and the solution was evaporated. The residual liquid was then hexane several times. The residual ionic liquid and activated carbon were added in acetonitrile and stirred at room temperature overnight. The solution was filtered and evaporated. The colorless ionic liquid was dried in vacuo at $40{ }^{\circ} \mathrm{C}$ for approximately 20 hours. The obtained liquid $\left(\left[\mathrm{P}_{444(2 \mathrm{~S} 2)}\right] \mathrm{Cl}, 2.6 \mathrm{~g}, 8 \mathrm{mmol}\right)$ was then successively dissolved in water, and aqueous solution of lithium bis(fluorosulfonyl)amide $(2.4 \mathrm{~g}, 13 \mathrm{mmol})$ was added. After the mixture was stirred at room temperature for 1.5 hours, it was settled. The ionic liquid phase was washed with water and hexane several times. The obtained ionic liquid was then dried in vacuo at $40{ }^{\circ} \mathrm{C}$ for more than 2 days. The yield was $54 \%(2.4 \mathrm{~g})$. ${ }^{1} \mathrm{H}-\mathrm{NMR}\left(400 \mathrm{MHz}, \mathrm{CDCl}_{3}\right): \delta=0.98\left(\mathrm{t}, J=6.8 \mathrm{~Hz}, \mathrm{PCH}_{2} \mathrm{CH}_{2} \mathrm{CH}_{2} \mathrm{CH}_{3}, 9 \mathrm{H}\right), \delta=1.28\left(\mathrm{t}, J=7.3 \mathrm{~Hz}, \mathrm{SCH}_{2} \mathrm{CH}_{3}\right.$, $3 \mathrm{H}), \delta=1.53\left(\mathrm{~m}, \mathrm{PCH}_{2} \mathrm{CH}_{2} \mathrm{CH}_{2} \mathrm{CH}_{3}, 12 \mathrm{H}\right), \delta=2.20\left(\mathrm{~m}, \mathrm{PCH}_{2} \mathrm{CH}_{2} \mathrm{CH}_{2} \mathrm{CH}_{3}, 6 \mathrm{H}\right), \delta=2.49$ (dt, $J=7.3$ and 12.2 $\mathrm{Hz} \mathrm{SCH}_{2} \mathrm{CH}_{3}, 2 \mathrm{H}$ ), $\delta=2.64\left(\mathrm{q}, J=7.5 \mathrm{~Hz} \mathrm{PCH}_{2} \mathrm{CH}_{2} \mathrm{~S}, 2 \mathrm{H}\right), \delta=2.82\left(\mathrm{dt}, J=7.3\right.$ and $14.7 \mathrm{~Hz} \mathrm{PCH}_{2} \mathrm{CH}_{2} \mathrm{~S}, 2 \mathrm{H}$ ). Elemental analysis: $\mathrm{C}_{16} \mathrm{H}_{36} \mathrm{~F}_{2} \mathrm{NO}_{4} \mathrm{PS}_{3}$ : Calcd. C 40.75, H 7.69, N 2.97. Found C 40.53, H 7.57, N 2.78.

\subsection{Triethyl[(methylthio)methyl]phosphonium tetrafluoroborate, $\left[\mathrm{P}_{222(1 S 1)}\right]\left[B \mathrm{BF}_{4}\right]$.}

Chloromethyl methyl sulfide $(2.5 \mathrm{~mL}, 30 \mathrm{mmol})$ was added to triethylphosphine toluene solution $(20 \%, 15 \mathrm{~mL}$, $20 \mathrm{mmol}$ ) at nitrogen atmosphere in a flask equipped with a reflux condenser and magnetic stirrer. The solution was stirred, and then heated to ca. $120{ }^{\circ} \mathrm{C}$ in an oil bath for 18 hours while stirring. After that, the flask was allowed to cool to room temperature. The toluene layer was removed and the solid was washed with toluene several times. Then the solid was dissolved by acetonitrile, and the solution was evaporated. The solid was dried in vacuo at $40{ }^{\circ} \mathrm{C}$ for approximately 3 hours. The obtained solid $\left(\left[\mathrm{P}_{222(1 \mathrm{~S} 1)}\right] \mathrm{Cl}, 4.2 \mathrm{~g}, 20\right.$ mmol) was then successively dissolved in acetonitrile, and sodium tetrafluoroborate (2.6 g, $23 \mathrm{mmol})$ was added. After the mixture was stirred at room temperature for more than one day, the solid in the solution was removed by filtration. The solution phase was evaporated and the residual solid was washed with hexane several times. The liquid was then dissolved in chloroform and the solution was washed with water several times. The solution was then evaporated, and the residual solid was washed with ethanol-diethyl ether mixture several times. The solid and anhydrous magnesium sulfate were added in chloroform, and stirred at room temperature overnight. The solution was filtered and then evaporated. The obtained solid was then dried in vacuo at $40{ }^{\circ} \mathrm{C}$ for more than 1 days. The yield was $46 \%(3.2 \mathrm{~g}) . \quad{ }^{1} \mathrm{H}-\mathrm{NMR}\left(400 \mathrm{MHz}, d_{6}\right.$-DMSO): $\delta=1.16\left(\mathrm{tt}, J=7.7\right.$ and $\left.18.4 \mathrm{~Hz}, \mathrm{PCH}_{2} \mathrm{CH}_{3}, 9 \mathrm{H}\right), \delta=2.29\left(\mathrm{~m}, \mathrm{PCH}_{2} \mathrm{CH}_{3}\right.$ and $\left.\mathrm{PCH}_{2} \mathrm{SCH}_{3}, 9 \mathrm{H}\right), \delta=3.55(\mathrm{~d}, J=$ 
$\left.9.5 \mathrm{~Hz}, \mathrm{PCH}_{2} \mathrm{SCH}_{3}, 2 \mathrm{H}\right)$. Elemental analysis: $\mathrm{C}_{8} \mathrm{H}_{20} \mathrm{BF}_{4} \mathrm{PS}$ : Calcd. $\mathrm{C} 36.11, \mathrm{H} 7.58, \mathrm{~N}$ 0. Found C 35.88, $\mathrm{H}$ $7.43, \mathrm{~N}-0.13$.

\subsection{Triethyl(2-methylthioethyl)phosphonium tetrafluoroborate, $\left[P_{222(I S 2)}\right]\left[B F_{4}\right]$.}

2-Chloroethyl methyl sulfide was distilled before use. The distilled 2-chloroethyl methyl sulfide (1.9 mL, 19 mmol) was added to triethylphosphine toluene solution $(20 \%, 10 \mathrm{~mL}, 15 \mathrm{mmol})$ at nitrogen atmosphere in a flask equipped with a reflux condenser and magnetic stirrer. The solution was stirred and then heated to ca. $120^{\circ} \mathrm{C}$ in an oil bath for 21 hours while stirring. After that, the flask was allowed to cool to room temperature. The toluene layer was removed, and the solid was dissolved by acetonitrile, and the solution was evaporated. The residual solid was then washed with diethyl ether several times, and the solution was evaporated. The

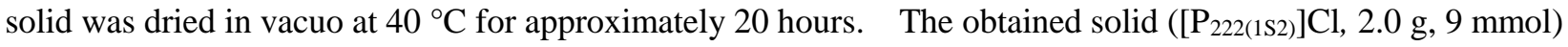
and sodium tetrafluoroborate $(1.4 \mathrm{~g}, 13 \mathrm{mmol})$ were dissolved in 1:1 (v/v) mixtures of water and acetone, respectively. The solutions were then mixed. After the mixture was stirred at room temperature for one day, the solution was evaporated. The residual solid was dissolved in chloroform, and the solution was washed with water several times. The solution was then evaporated and the residual solid washed with hexane several times. The solid and anhydrous magnesium sulfate were added in chloroform, and stirred at room temperature overnight. The solution was filtered and evaporated. The obtained solid was then dried in vacuo at $40{ }^{\circ} \mathrm{C}$ for more than 1 days. The yield was $28 \%(1.2 \mathrm{~g}) . \quad{ }^{1} \mathrm{H}-\mathrm{NMR}\left(400 \mathrm{MHz}, \mathrm{CDCl}_{3}\right): \delta=1.30(\mathrm{dt}, J=7.7$ and 18.4 $\mathrm{Hz}, \mathrm{PCH}_{2} \mathrm{CH}_{3}, 9 \mathrm{H}$ ), $\delta=2.21$ (s, $\mathrm{SCH}_{2} \mathrm{CH}_{3}, 3 \mathrm{H}$ ), $\delta=2.33$ (dq, $J=7.7$ and $13 \mathrm{~Hz}, \mathrm{PCH}_{2} \mathrm{CH}_{3}, 6 \mathrm{H}$ ), $\delta=2.58$ (dt, $J$ $=7.7$ and $\left.12.5 \mathrm{~Hz}, \mathrm{PCH}_{2} \mathrm{CH}_{2} \mathrm{~S}, 2 \mathrm{H}\right), \delta=2.81\left(\mathrm{dt}, J=7.5\right.$ and $\left.13.1 \mathrm{~Hz}, \mathrm{PCH}_{2} \mathrm{CH}_{2} \mathrm{~S}, 2 \mathrm{H}\right)$. Elemental analysis: $\mathrm{C}_{9} \mathrm{H}_{22} \mathrm{BF}_{4} \mathrm{PS}$ : Calcd. C 38.59, H 7.92, N 0. Found C 38.45, H 7.81, N -0.15.

\subsection{Triethyl[2-(ethylthio)ethyl]triethylphosphonium tetrafluoroborate, $\left[P_{222(2 S 2)}\right]\left[B F_{4}\right]$.}

2-Chloroethyl ethyl sulfide (2.9 mL, $25 \mathrm{mmol})$ was added to triethylphosphine toluene solution $(20 \%, 15 \mathrm{~mL}$, $20 \mathrm{mmol}$ ) at nitrogen atmosphere in a flask equipped with a reflux condenser and magnetic stirrer. The solution was stirred, and then heated to ca. $120{ }^{\circ} \mathrm{C}$ in an oil bath for 22 hours while stirring. After that, the flask was allowed to cool to room temperature. The solid was washed with toluene several times, then dissolved by acetonitrile, and the solution was evaporated. The solid was dried in vacuo at $40{ }^{\circ} \mathrm{C}$ for approximately 3 hours. The obtained solid $\left.\left(\left[\mathrm{P}_{222(2 \mathrm{~S} 2}\right)\right] \mathrm{Cl}, 4.4 \mathrm{~g}, 18 \mathrm{mmol}\right)$ was then successively dissolved in acetonitrile, and sodium tetrafluoroborate $(2.5 \mathrm{~g}, 23 \mathrm{mmol})$ was added. After the mixture was stirred at room temperature for more than one day, the solid in the solution was removed by filtration. The solution phase was evaporated and the residual solid was washed with hexane several times. The solid was then dissolved in methylene chloride and the solution was washed with water several times. The solution was then evaporated and the residual solid was washed with ethanol-diethyl ether mixture several times. The solid and anhydrous magnesium sulfate were added in chloroform, and stirred at room temperature overnight. The solution was filtered and then evaporated. The obtained solid was dried in vacuo at $40{ }^{\circ} \mathrm{C}$ for more than 1 days. The yield 
was $30 \%$ (2.8 g). $\quad{ }^{1} \mathrm{H}-\mathrm{NMR}\left(400 \mathrm{MHz}, \mathrm{CD}_{3} \mathrm{OD}\right): \delta=1.27$ (m, $\mathrm{PCH}_{2} \mathrm{CH}_{3}$ and $\mathrm{SCH}_{2} \mathrm{CH}_{3}, 12 \mathrm{H}$ ), $\delta=2.31$ (qq, $J$ $=7.7$ and $\left.12.9 \mathrm{~Hz}, \mathrm{PCH}_{2} \mathrm{CH}_{3}, 6 \mathrm{H}\right), \delta=2.56\left(\mathrm{~m}, \mathrm{PCH}_{2} \mathrm{CH}_{2} \mathrm{~S}, 2 \mathrm{H}\right), \delta=2.66\left(\mathrm{q}, J=7.5 \mathrm{~Hz}, \mathrm{SCH}_{2} \mathrm{CH}_{3}, 2 \mathrm{H}\right), \delta=$ $2.84\left(\mathrm{~m}, \mathrm{PCH}_{2} \mathrm{CH}_{2} \mathrm{~S}, 2 \mathrm{H}\right)$. Elemental analysis: $\mathrm{C}_{10} \mathrm{H}_{24} \mathrm{BF} 4 \mathrm{PS}$ : Calcd. C 40.83, $\mathrm{H}$ 8.22, $\mathrm{N}$ 0. Found $\mathrm{C} 40.51$, H 8.07, N -0.10.

\subsection{Tributyl[(methylthio)methyl]phosphonium tetrafluoroborate, $\left[\mathrm{P}_{444(1 S 1)}\right]\left[B \mathrm{BF}_{4}\right]$.}

The $\left[\mathrm{P}_{444(1 \mathrm{~S})}\right] \mathrm{Cl}(2.8 \mathrm{~g}, 9 \mathrm{mmol})$ synthesized in section 1.10 and sodium tetrafluoroborate $(1.4 \mathrm{~g}, 12 \mathrm{mmol})$ were dissolved in 1:1 (v/v) mixtures of water and acetone, respectively. The solutions were then mixed. After the mixture was stirred at room temperature for one day, the solution was evaporated. The aqueous phase was removed and organic phase washed with water five times. The solution was then evaporated and the residual liquid washed with hexane several times. The residual ionic liquid and anhydrous magnesium sulfate were added in chloroform, and stirred at room temperature overnight. The solution was filtered and evaporated. The obtained ionic liquid was then dried in vacuo at $40{ }^{\circ} \mathrm{C}$ for more than 2 days. The yield was 74\% (2.5 g). ${ }^{1} \mathrm{H}-\mathrm{NMR}$ (400 MHz, DMSO-d6): $\delta=0.92$ (t, $J=7.0 \mathrm{~Hz}, \mathrm{PCH}_{2} \mathrm{CH}_{2} \mathrm{CH}_{2} \mathrm{CH}_{3}, 9 \mathrm{H}$ ), $\delta=1.46$ (m, $\left.\mathrm{PCH}_{2} \mathrm{CH}_{2} \mathrm{CH}_{2} \mathrm{CH}_{3}, 12 \mathrm{H}\right), \delta=2.23\left(\mathrm{~m}, \mathrm{PCH}_{2} \mathrm{CH}_{2} \mathrm{CH}_{2} \mathrm{CH}_{3}, 6 \mathrm{H}\right), \delta=2.34\left(\mathrm{~d}, J=1.4, \mathrm{PCH}_{2} \mathrm{SCH}_{3}, 3 \mathrm{H}\right), \delta=3.37$ $\left(\mathrm{d}, J=9.5 \mathrm{~Hz}, \mathrm{PCH}_{2} \mathrm{SCH}_{3}, 2 \mathrm{H}\right)$. Elemental analysis: $\mathrm{C}_{14} \mathrm{H}_{32} \mathrm{BF}_{4} \mathrm{PS}$ : Calcd. C 48.01, $\mathrm{H}$ 9.21, $\mathrm{N} \mathrm{0.} \mathrm{Found} \mathrm{C}$ 47.71, H 9.17, N-0.10.

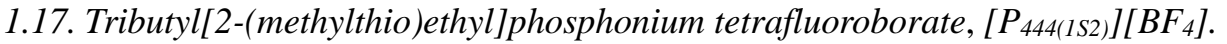

2-Chloroethyl methyl sulfide was distilled before use. The distilled 2-chloroethyl methyl sulfide (2 mL, 20 mmol) was added to tributylphosphine $(4 \mathrm{~mL}, 16 \mathrm{mmol})$ at nitrogen atmosphere in a flask equipped with a reflux condenser and magnetic stirrer. The solution was stirred, and then heated to ca. $120{ }^{\circ} \mathrm{C}$ in an oil bath for 24 hours while stirring. After that, the flask was allowed to cool to room temperature. The residual liquid was dissolved in acetonitrile, and the solution was evaporated. The residual liquid was then washed with hexane and diethyl ether several times, and the solution was evaporated. The ionic liquid was dried in vacuo at $40{ }^{\circ} \mathrm{C}$ for approximately 20 hours. The obtained liquid $\left(\left[\mathrm{P}_{444(1 \mathrm{~S} 2)}\right] \mathrm{Cl}, 4.6 \mathrm{~g}, 15 \mathrm{mmol}\right)$ and sodium tetrafluoroborate $(2.3 \mathrm{~g}, 20 \mathrm{mmol})$ were dissolved in 1:1 (v/v) mixtures of water and acetone, respectively. The solutions were then mixed. After the mixture was stirred at room temperature for one day, the solution was evaporated. The residual liquid was dissolved in chloroform, and the solution was washed with water several times. The solution was then evaporated and the residual liquid washed with hexane several times. The residual ionic liquid and anhydrous magnesium sulfate were added in chloroform, and stirred at room temperature overnight. The solution was filtered and evaporated. The obtained ionic liquid was then dried in vacuo at $40{ }^{\circ} \mathrm{C}$ for more than 2 days. The yield was $77 \%(4.4 \mathrm{~g}) .{ }^{1} \mathrm{H}-\mathrm{NMR}\left(400 \mathrm{MHz}, \mathrm{CDCl}_{3}\right): \delta=0.92$ (m, $\left.\mathrm{PCH}_{2} \mathrm{CH}_{2} \mathrm{CH}_{2} \mathrm{CH}_{3}, 9 \mathrm{H}\right), \delta=1.52\left(\mathrm{~m}, \mathrm{PCH}_{2} \mathrm{CH}_{2} \mathrm{CH}_{2} \mathrm{CH}_{3}, 12 \mathrm{H}\right), \delta=2.25\left(\mathrm{~m}, \mathrm{PCH}_{2} \mathrm{CH}_{2} \mathrm{CH}_{2} \mathrm{CH}_{3}, 6 \mathrm{H}\right.$, and $\left.\mathrm{SCH}_{3}, 3 \mathrm{H}\right), \delta=2.55\left(\mathrm{~m}, \mathrm{PCH}_{2} \mathrm{CH}_{2} \mathrm{~S}, 2 \mathrm{H}\right), \delta=2.82\left(\mathrm{~m}, \mathrm{PCH}_{2} \mathrm{CH}_{2} \mathrm{~S}, 2 \mathrm{H}\right)$. Elemental analysis: $\mathrm{C}_{15} \mathrm{H}_{34} \mathrm{BF}_{4} \mathrm{PS}$ : Calcd. C 49.46, H 9.41, N 0. Found C 49.22, H 9.38, N -0.12. 


\subsection{Tributyl[2-(ethylthio)ethyl]phosphonium tetrafluoroborate, $\left[P_{444(2 S 2)}\right]\left[B F_{4}\right]$.}

2-Chloroethyl ethyl sulfide $(2.5 \mathrm{~mL}, 22 \mathrm{mmol})$ was added to tributylphosphine $(4 \mathrm{~mL}, 16 \mathrm{mmol})$ at nitrogen atmosphere in a flask equipped with a reflux condenser and magnetic stirrer. The solution was stirred, and then heated to ca. $120{ }^{\circ} \mathrm{C}$ in an oil bath for 20 hours while stirring. After that, the flask was allowed to cool to room temperature. The residual liquid was dissolved in acetonitrile, and the solution was evaporated. The residual liquid was then washed with hexane several times, and the solution was evaporated. The ionic liquid was dried in vacuo at $40{ }^{\circ} \mathrm{C}$ for approximately 20 hours. The obtained liquid $\left(\left[\mathrm{P}_{444(2 \mathrm{~S} 2)}\right] \mathrm{Cl}, 5.1 \mathrm{~g}, 15 \mathrm{mmol}\right)$ and sodium tetrafluoroborate $(2.5 \mathrm{~g}, 21 \mathrm{mmol})$ were dissolved in 1:1 (v/v) mixtures of water and acetone, respectively. The solutions were then mixed. After the mixture was stirred at room temperature for one day, the solution was evaporated. The aqueous phase was removed and the organic phase was washed with water several times. The solution was then evaporated and the residual liquid was washed with hexane several times. The residual ionic liquid and anhydrous magnesium sulfate were added in chloroform, and stirred at room temperature overnight. The solution was filtered and evaporated. The obtained ionic liquid was then dried in vacuo at $40{ }^{\circ} \mathrm{C}$ for more than 2 days. The yield was $81 \%(4.8 \mathrm{~g})$. ${ }^{1} \mathrm{H}-\mathrm{NMR}\left(400 \mathrm{MHz}, \mathrm{CDCl}_{3}\right): \delta=0.94$ (t, $\left.J=6.8 \mathrm{~Hz}, \mathrm{PCH}_{2} \mathrm{CH}_{2} \mathrm{CH}_{2} \mathrm{CH}_{3}, 9 \mathrm{H}\right), \delta=1.24\left(\mathrm{t}, J=7.5 \mathrm{~Hz}, \mathrm{SCH}_{2} \mathrm{CH}_{3}, 3 \mathrm{H}\right), \delta=1.50(\mathrm{~m}, \mathrm{~Hz}$, $\left.\mathrm{PCH}_{2} \mathrm{CH}_{2} \mathrm{CH}_{2} \mathrm{CH}_{3}, 12 \mathrm{H}\right), \delta=2.22\left(\mathrm{~m}, \mathrm{PCH}_{2} \mathrm{CH}_{2} \mathrm{CH}_{2} \mathrm{CH}_{3}, 6 \mathrm{H}\right), \delta=2.51$ (dt, $J=7.5$ and $12.5 \mathrm{~Hz}, \mathrm{PCH}_{2} \mathrm{CH}_{2} \mathrm{~S}$, $2 \mathrm{H}), \delta=2.62\left(\mathrm{q}, J=7.3 \mathrm{~Hz}, \mathrm{SCH}_{2} \mathrm{CH}_{3}, 2 \mathrm{H}\right), \delta=2.80\left(\mathrm{dt}, J=7.25\right.$ and $\left.13.8 \mathrm{~Hz}, \mathrm{PCH}_{2} \mathrm{CH}_{2} \mathrm{~S}, 2 \mathrm{H}\right)$. Elemental analysis: $\mathrm{C}_{16} \mathrm{H}_{36} \mathrm{BF}_{4} \mathrm{PS}$ : Calcd. C 50.80, H 9.59, N 0. Found C 50.55, H 9.54, N -0.06. 
2. Water Contents of ILs Used in This Study.

Table S1. Water Contents of Sample ILs.

\begin{tabular}{cc}
\hline $\mathrm{IL}$ & Water Content $(\mathrm{ppm})$ \\
\hline$\left[\mathrm{P}_{222(1 \mathrm{~S} 1)}\right]\left[\mathrm{NTf}_{2}\right]$ & 62.5 \\
{$\left[\mathrm{P}_{222(1 \mathrm{~S} 2)]\left[\mathrm{NTf}_{2}\right]}\right.$} & 35.0 \\
{$\left[\mathrm{P}_{222(2 \mathrm{~S} 2)}\right]\left[\mathrm{NTf}_{2}\right]$} & 61.6 \\
{$\left[\mathrm{P}_{444(1 \mathrm{~S} 1)}\right]\left[\mathrm{NTf}_{2}\right]$} & 84.2 \\
{$\left[\mathrm{P}_{444(1 \mathrm{~S} 2)}\right]\left[\mathrm{NTf}_{2}\right]$} & 86.4 \\
{$\left[\mathrm{P}_{444(2 \mathrm{~S} 2)}\right]\left[\mathrm{NTf}_{2}\right]$} & 54.2 \\
{$\left[\mathrm{P}_{222(1 \mathrm{~S} 1)}\right]\left[\mathrm{NF}_{2}\right]$} & 46.5 \\
{$\left[\mathrm{P}_{222(1 \mathrm{~S} 2)}\right]\left[\mathrm{NF}_{2}\right]$} & 42.4 \\
{$\left[\mathrm{P}_{222(2 \mathrm{~S} 2)}\right]\left[\mathrm{NF}_{2}\right]$} & 45.5 \\
{$\left[\mathrm{P}_{444(1 \mathrm{~S} 1)}\right]\left[\mathrm{NF}_{2}\right]$} & 50.4 \\
{$\left[\mathrm{P}_{444(1 \mathrm{~S} 2)}\right]\left[\mathrm{NF}_{2}\right]$} & 64.9 \\
{$\left[\mathrm{P}_{444(2 \mathrm{~S} 2)}\right]\left[\mathrm{NF}_{2}\right]$} & 42.1 \\
{$\left[\mathrm{P}_{444(1 \mathrm{~S} 1)}\right]\left[\mathrm{BF}_{4}\right]$} & 113.0 \\
{$\left[\mathrm{P}_{444(1 \mathrm{~S} 2)}\right]\left[\mathrm{BF}_{4}\right]$} & 104.3 \\
{$\left[\mathrm{P}_{444(2 \mathrm{~S} 2)}\right]\left[\mathrm{BF}_{4}\right]$} & 99.2
\end{tabular}


3. ${ }^{1} \mathrm{H}$ NMR Spectra of Ionic Liquids.

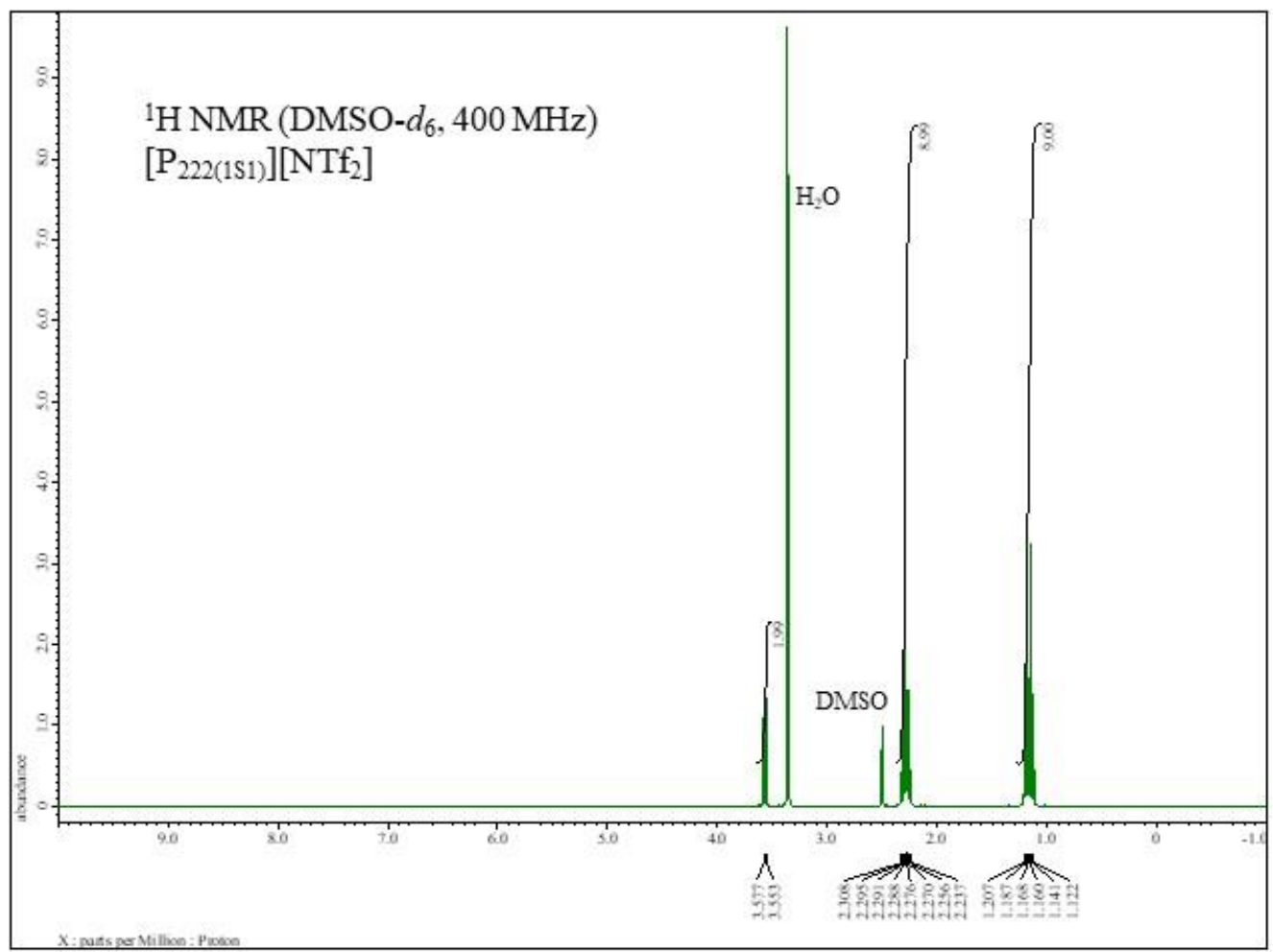

Figure $\mathrm{S} 1 . \quad{ }^{1} \mathrm{H}$ NMR spectrum for $\left[\mathrm{P}_{222(1 \mathrm{~S} 1)}\right]\left[\mathrm{NTf}_{2}\right]$.

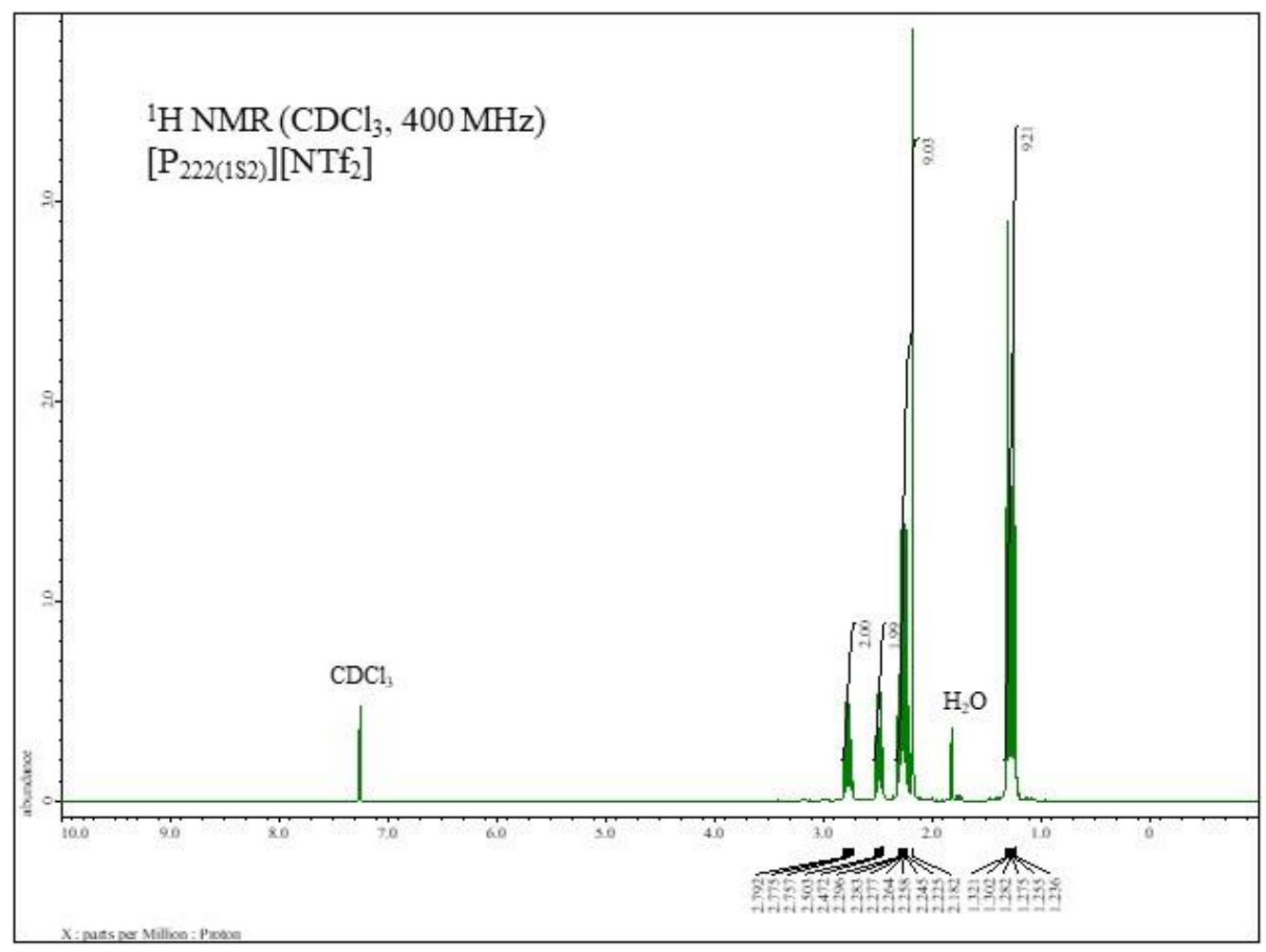

Figure $\mathrm{S} 2 . \quad{ }^{1} \mathrm{H}$ NMR spectrum for $\left[\mathrm{P}_{222(1 \mathrm{~S} 2)]}\left[\mathrm{NTf}_{2}\right]\right.$. 


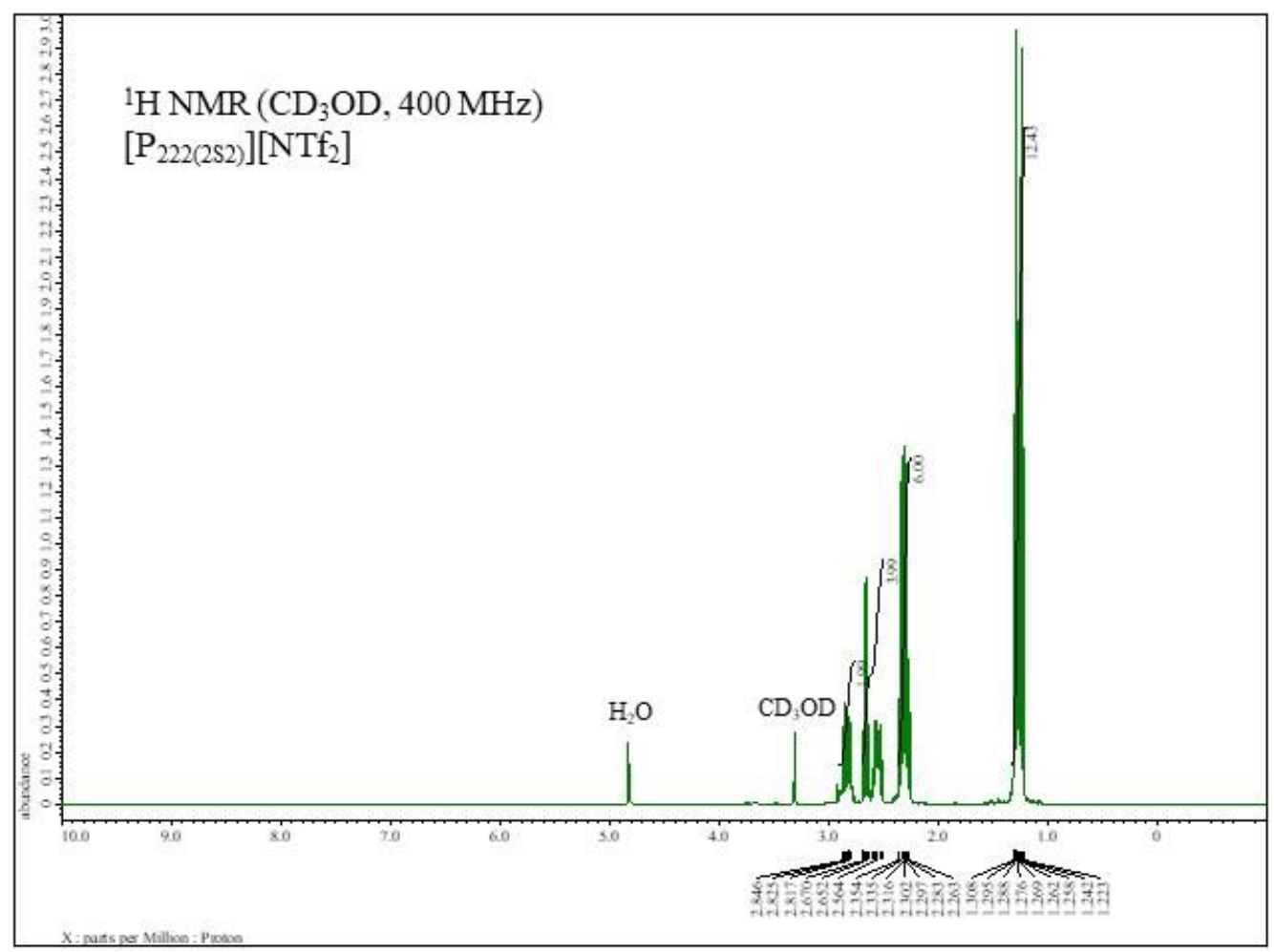

Figure $\mathrm{S} 3 . \quad{ }^{1} \mathrm{H}$ NMR spectrum for $\left[\mathrm{P}_{222(2 \mathrm{~S} 2)}\right]\left[\mathrm{NTf}_{2}\right]$.

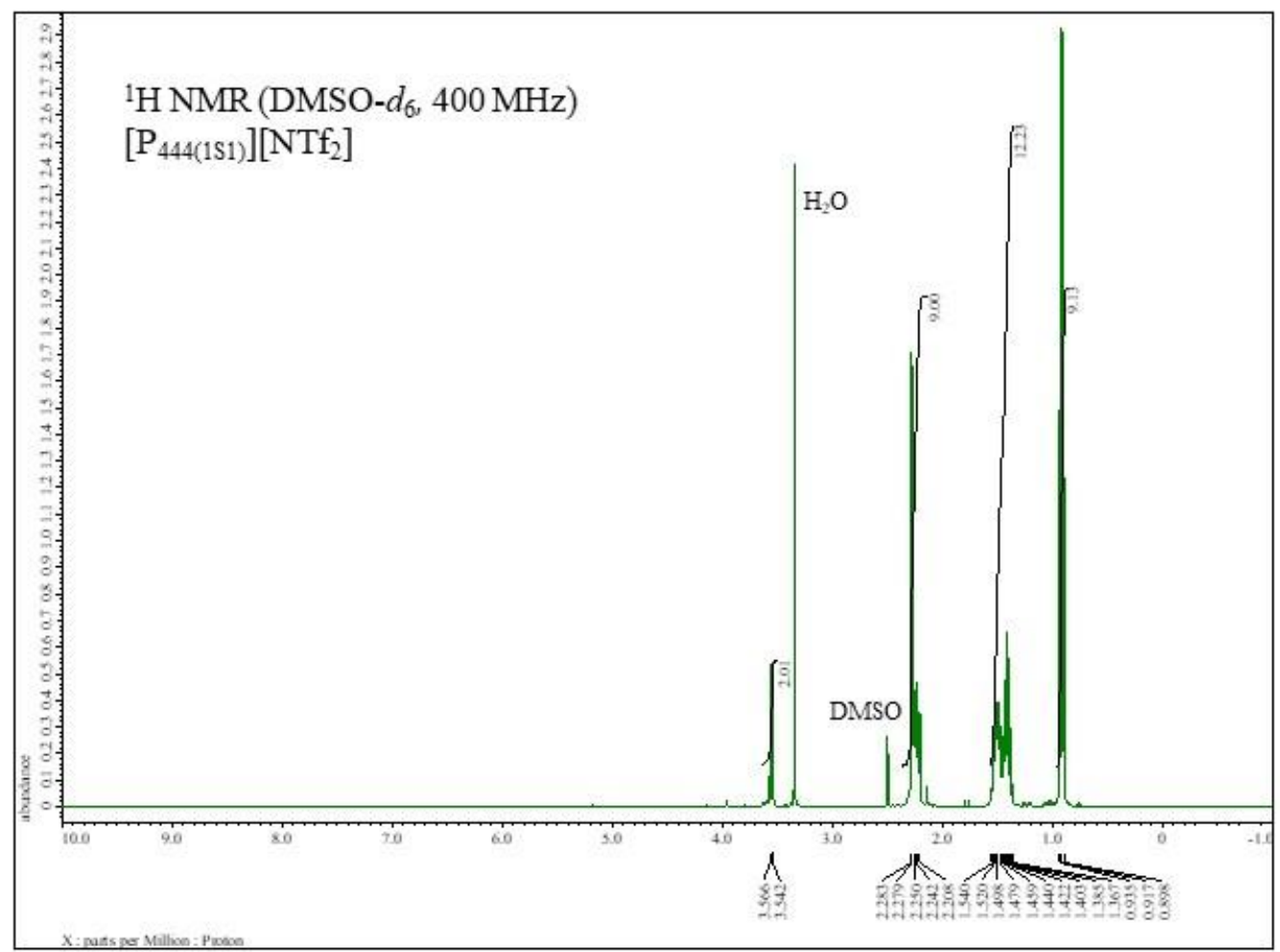

Figure S4. ${ }^{1} \mathrm{H}$ NMR spectrum for $\left[\mathrm{P}_{444(1 \mathrm{~S})}\right]\left[\mathrm{NTf}_{2}\right]$. 


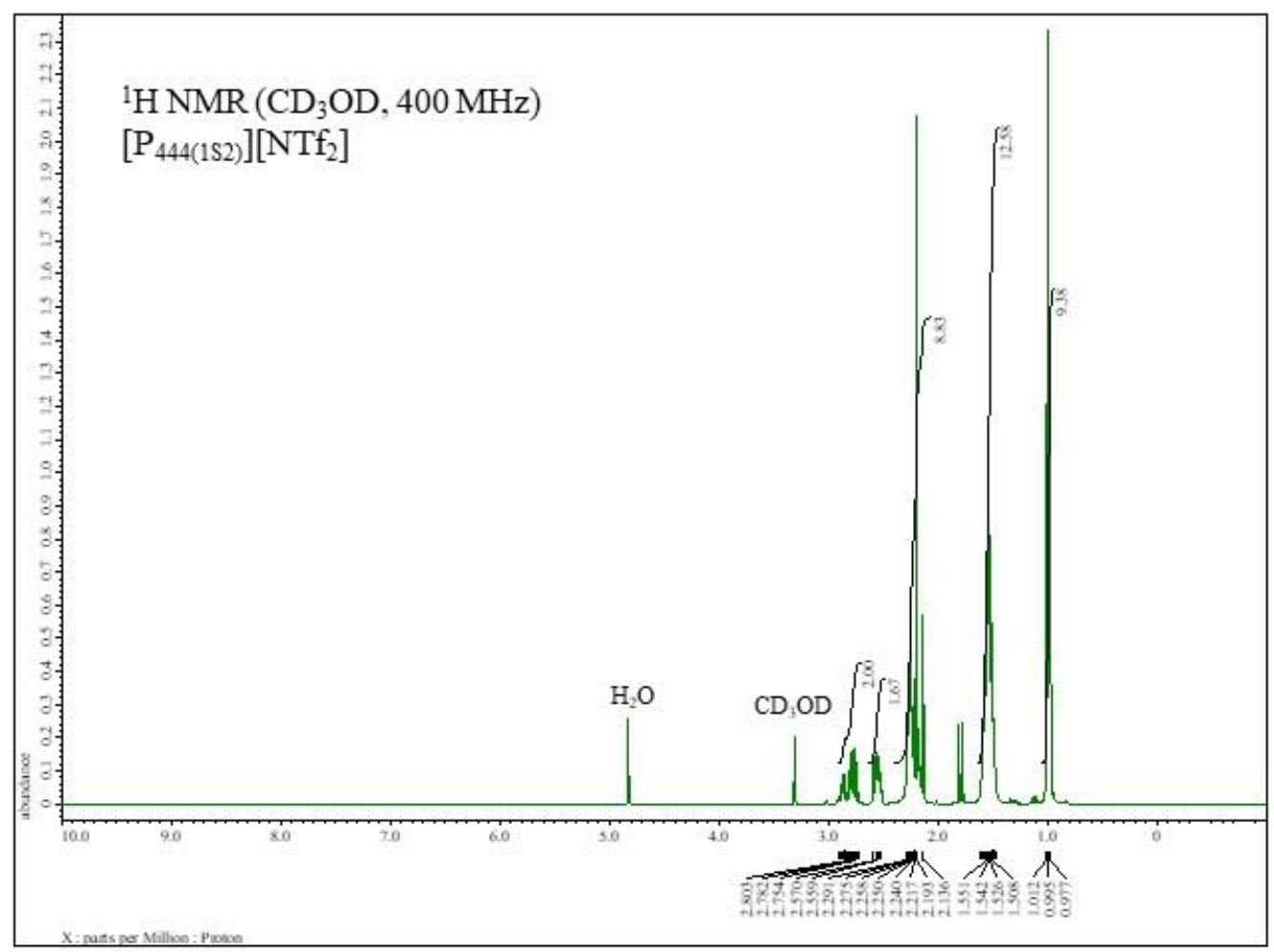

Figure S5. ${ }^{1} \mathrm{H}$ NMR spectrum for $\left[\mathrm{P}_{444(1 \mathrm{~S} 2)]}\left[\mathrm{NTf}_{2}\right]\right.$.

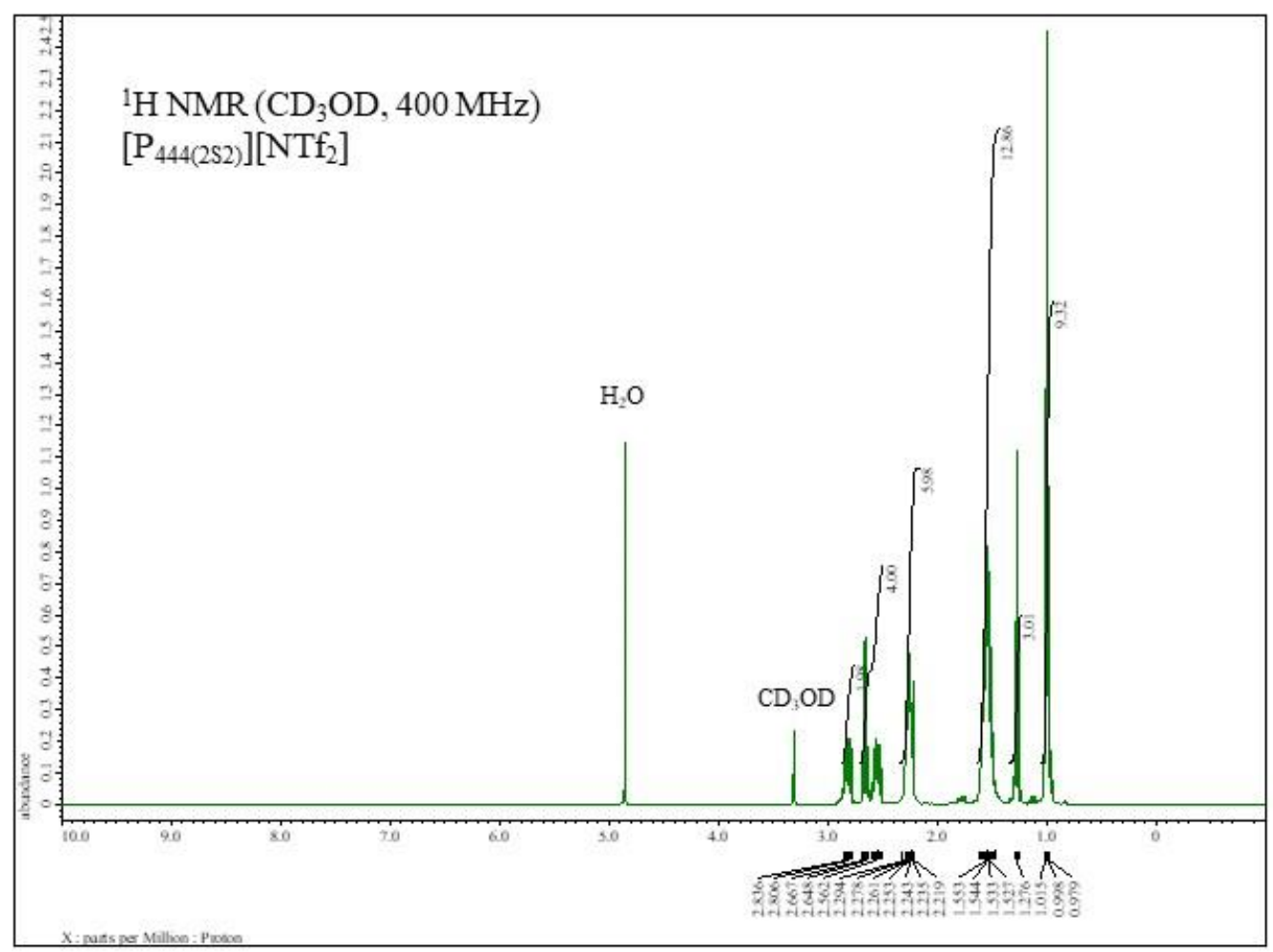

Figure S6. $\quad{ }^{1} \mathrm{H}$ NMR spectrum for $\left[\mathrm{P}_{444(2 \mathrm{~S} 2)}\right]\left[\mathrm{NTf}_{2}\right]$. 


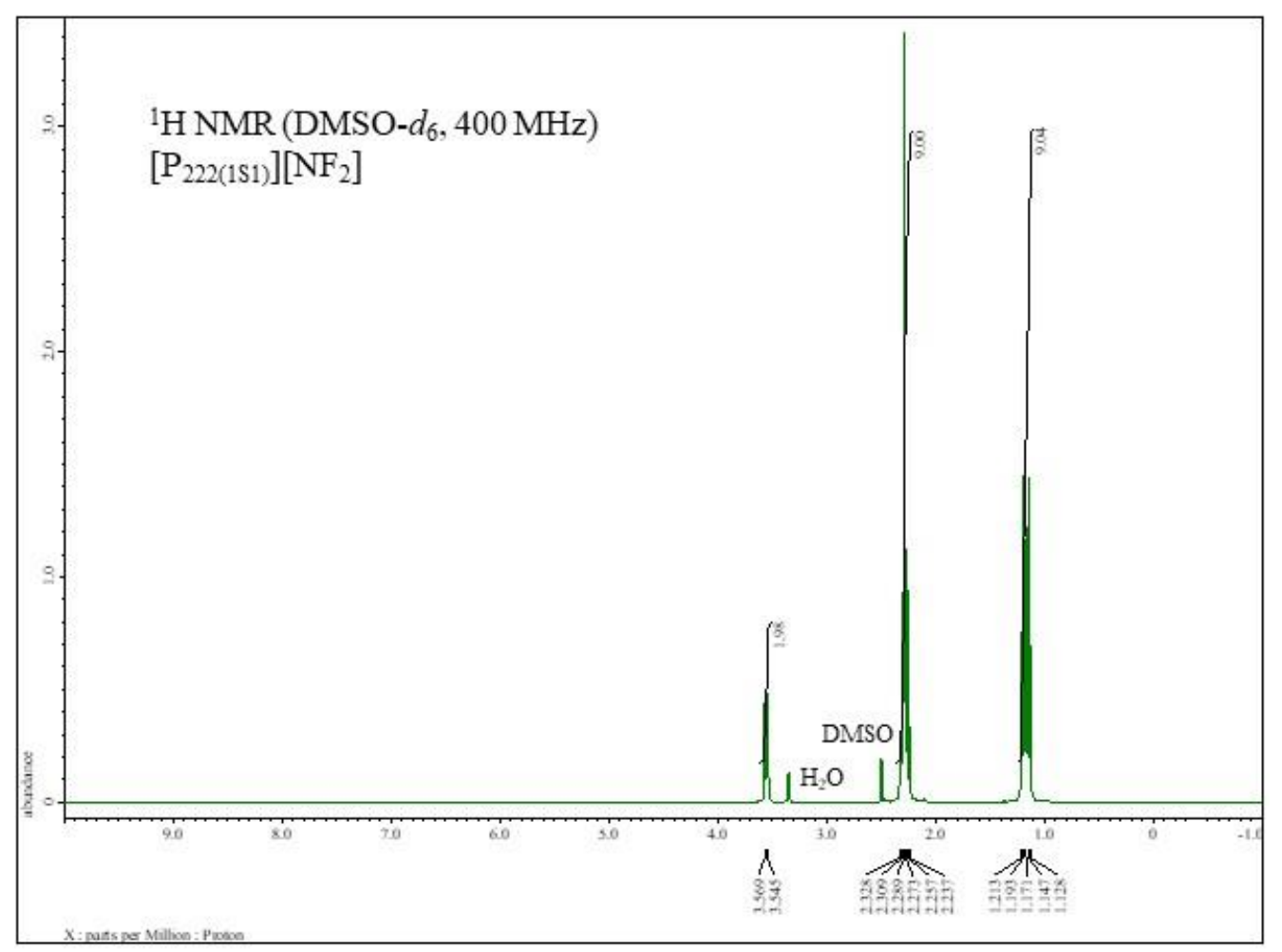

Figure S7. $\quad{ }^{1} \mathrm{H}$ NMR spectrum for $\left[\mathrm{P}_{222(1 \mathrm{~S} 1)}\right]\left[\mathrm{NF}_{2}\right]$.

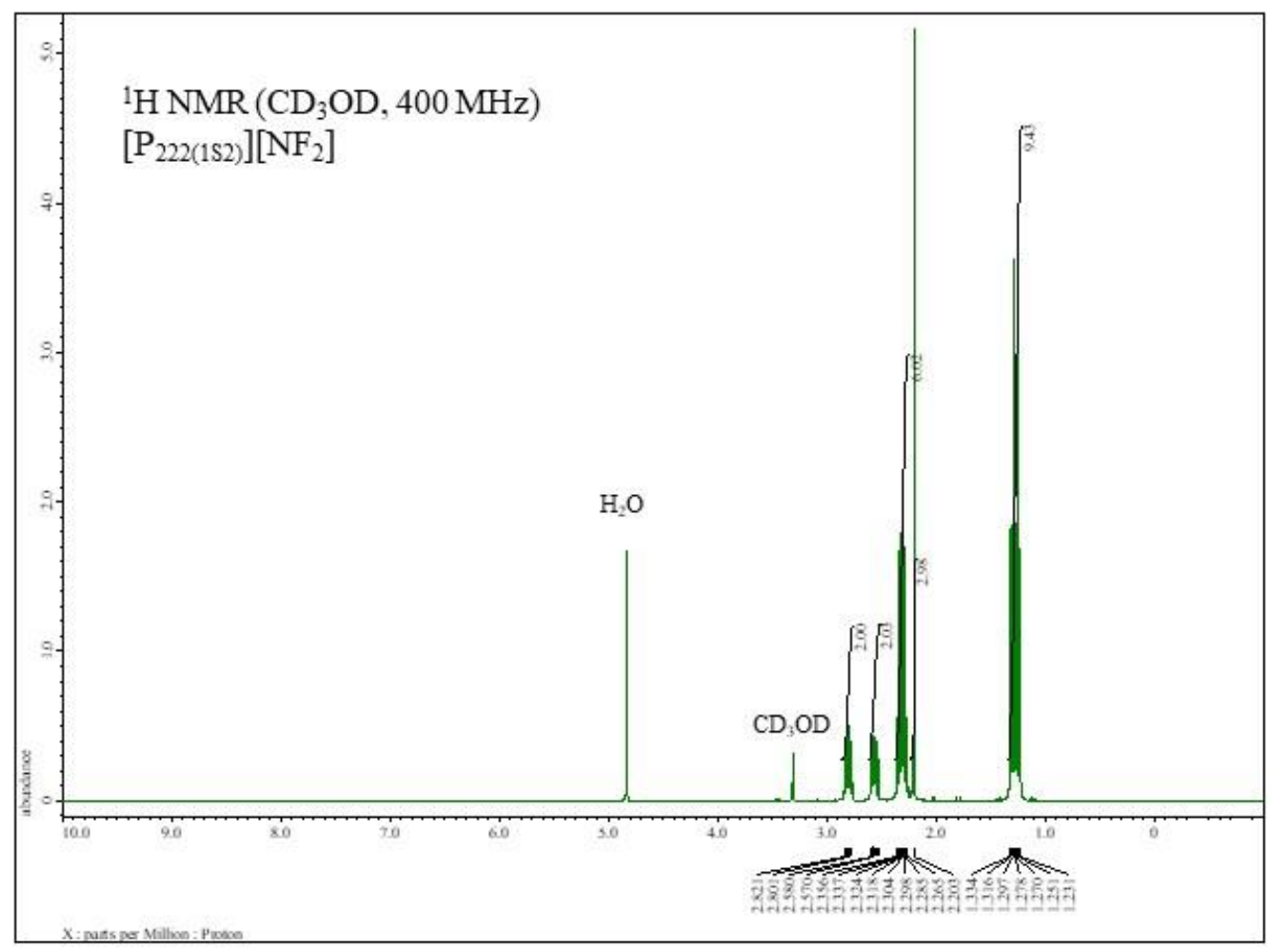

Figure S8. $\quad{ }^{1} \mathrm{H}$ NMR spectrum for $\left[\mathrm{P}_{222(1 \mathrm{~S} 2)}\right]\left[\mathrm{NF}_{2}\right]$. 


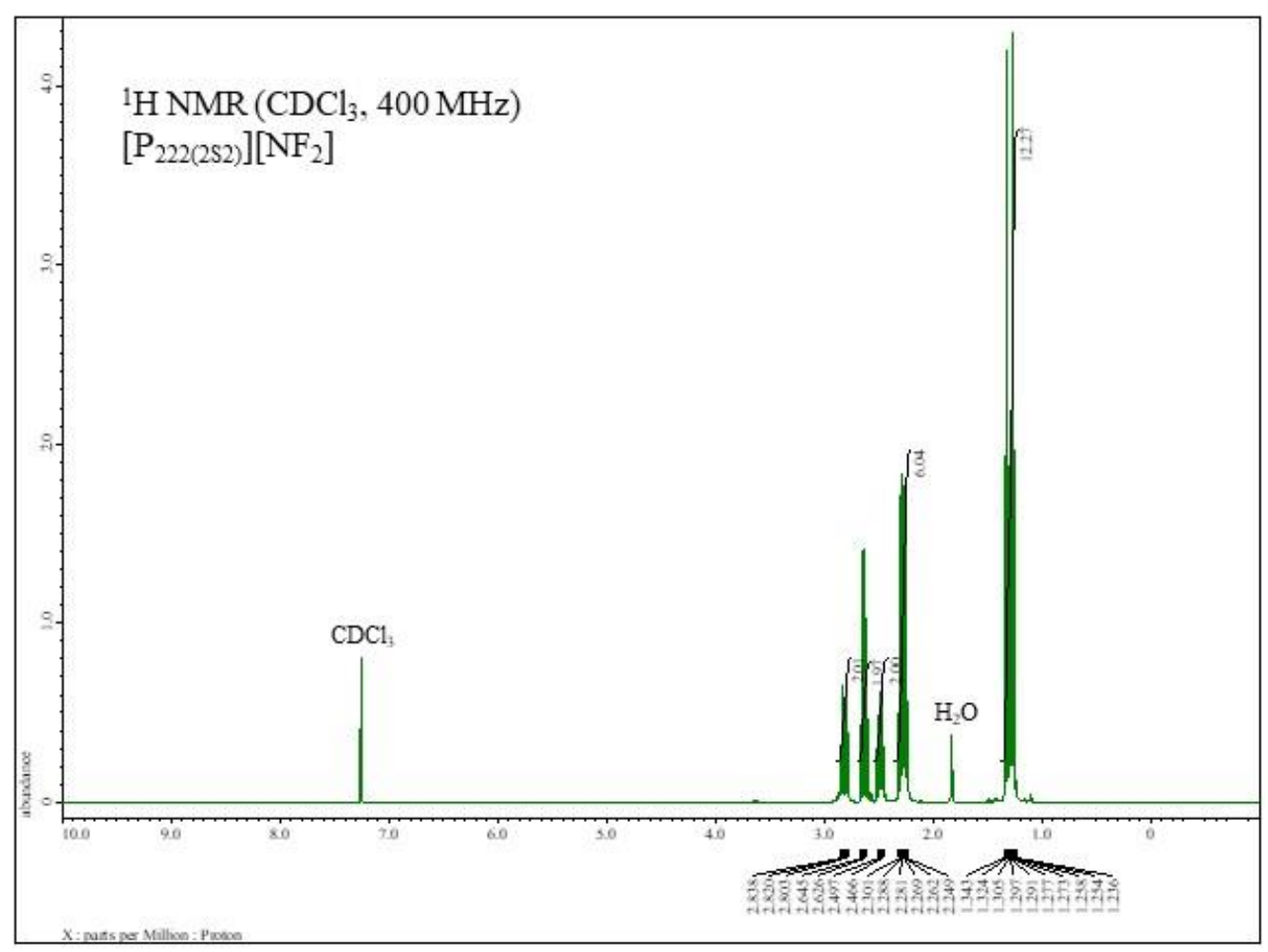

Figure S9. $\quad{ }^{1} \mathrm{H}$ NMR spectrum for $\left[\mathrm{P}_{222(2 \mathrm{~S} 2)}\right]\left[\mathrm{NF}_{2}\right]$.

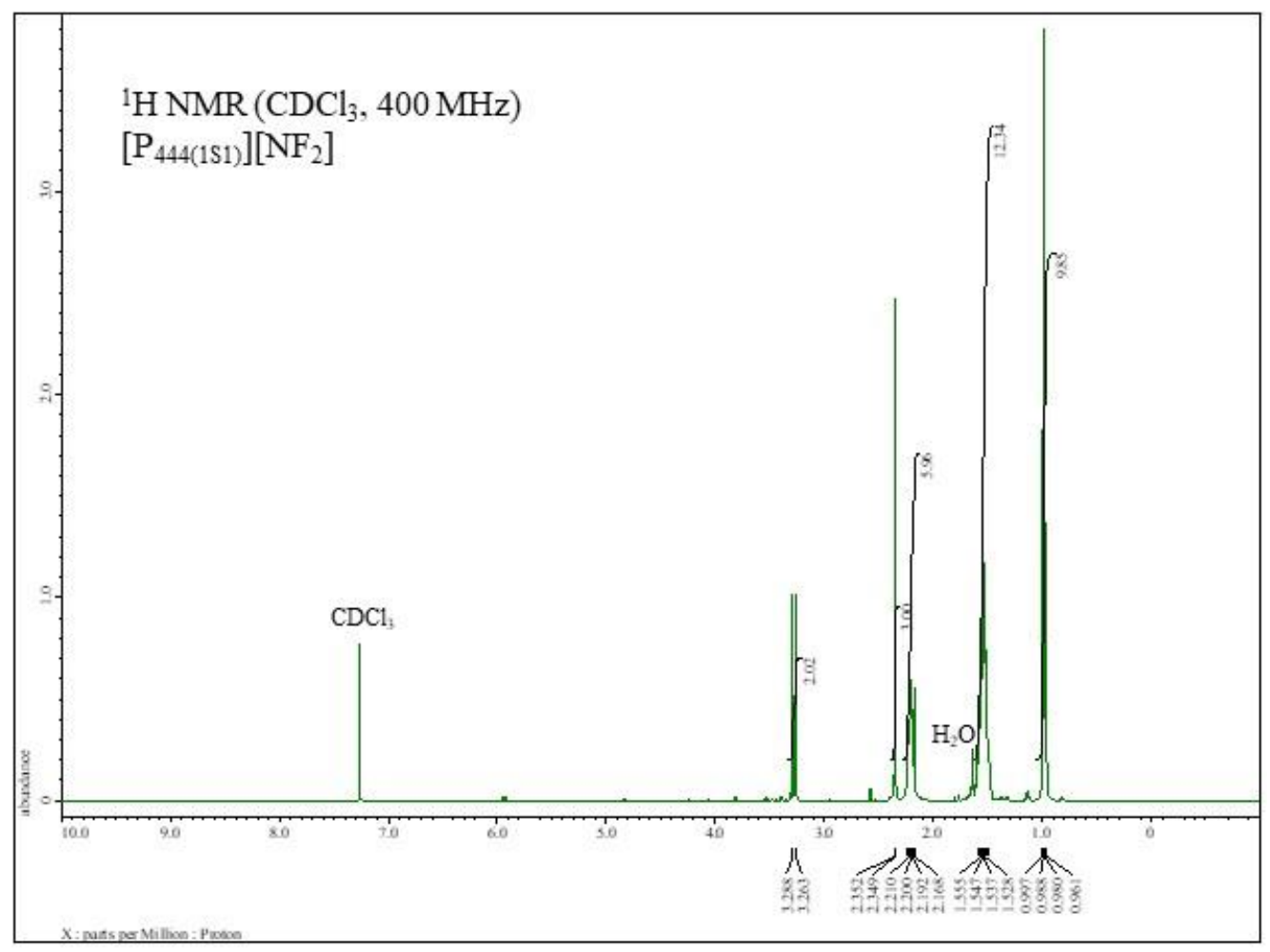

Figure $\mathrm{S} 10 . \quad{ }^{1} \mathrm{H}$ NMR spectrum for $\left[\mathrm{P}_{444(1 \mathrm{~S} 1)}\right]\left[\mathrm{NF}_{2}\right]$. 


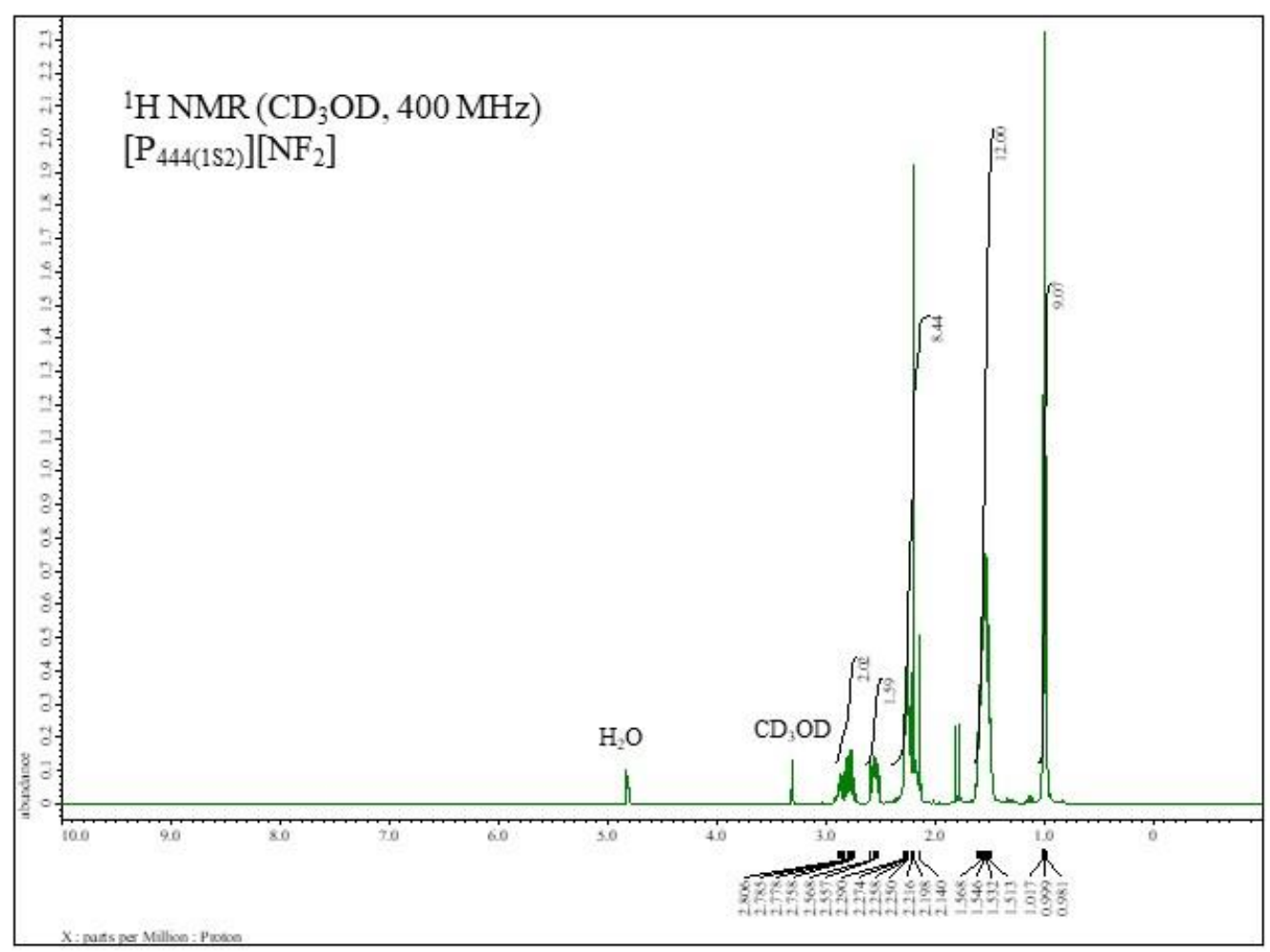

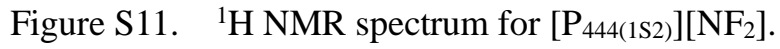

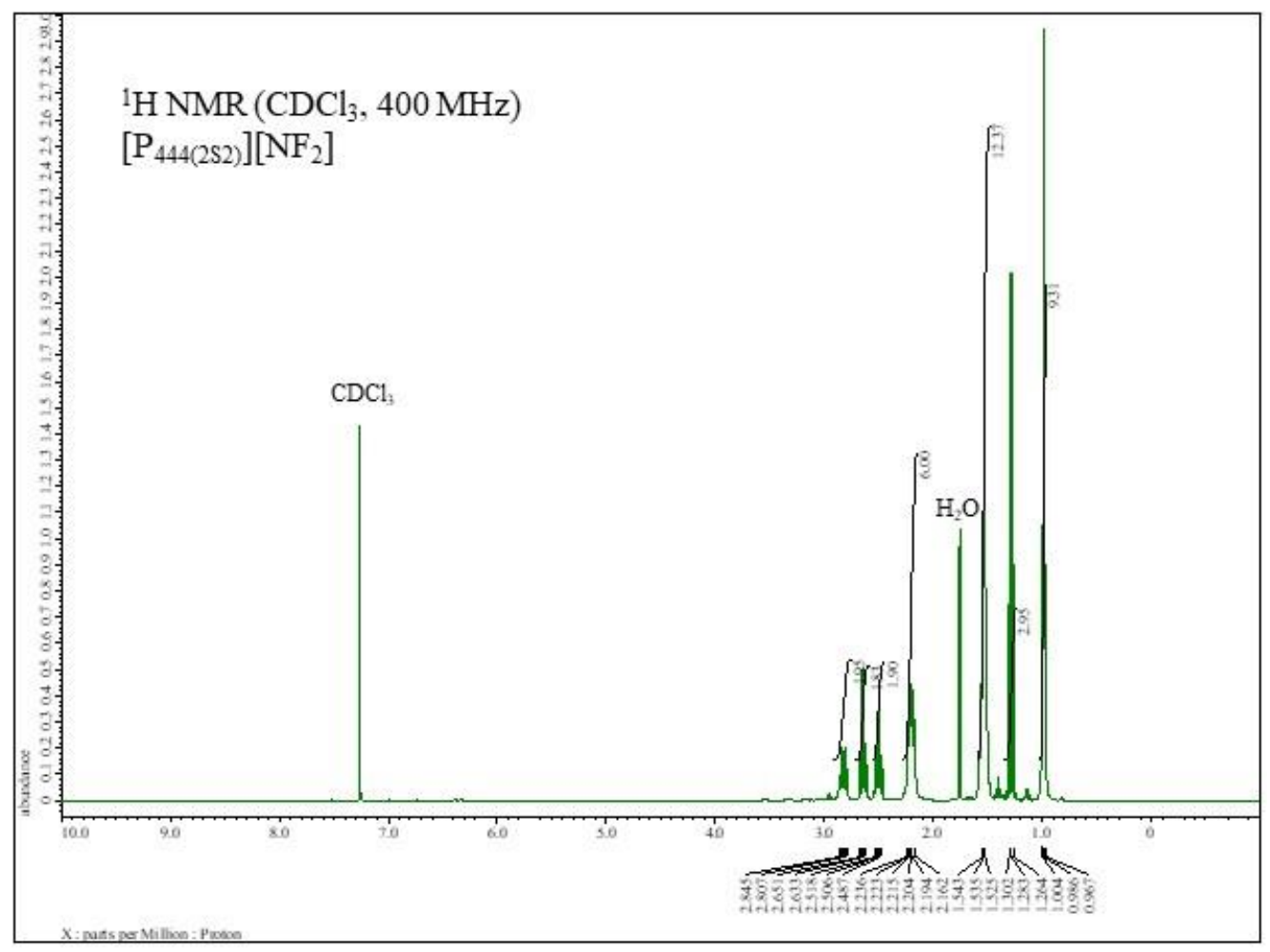

Figure $\mathrm{S} 12 . \quad{ }^{1} \mathrm{H} \mathrm{NMR}$ spectrum for $\left[\mathrm{P}_{444(2 \mathrm{~S} 2)}\right]\left[\mathrm{NF}_{2}\right]$. 


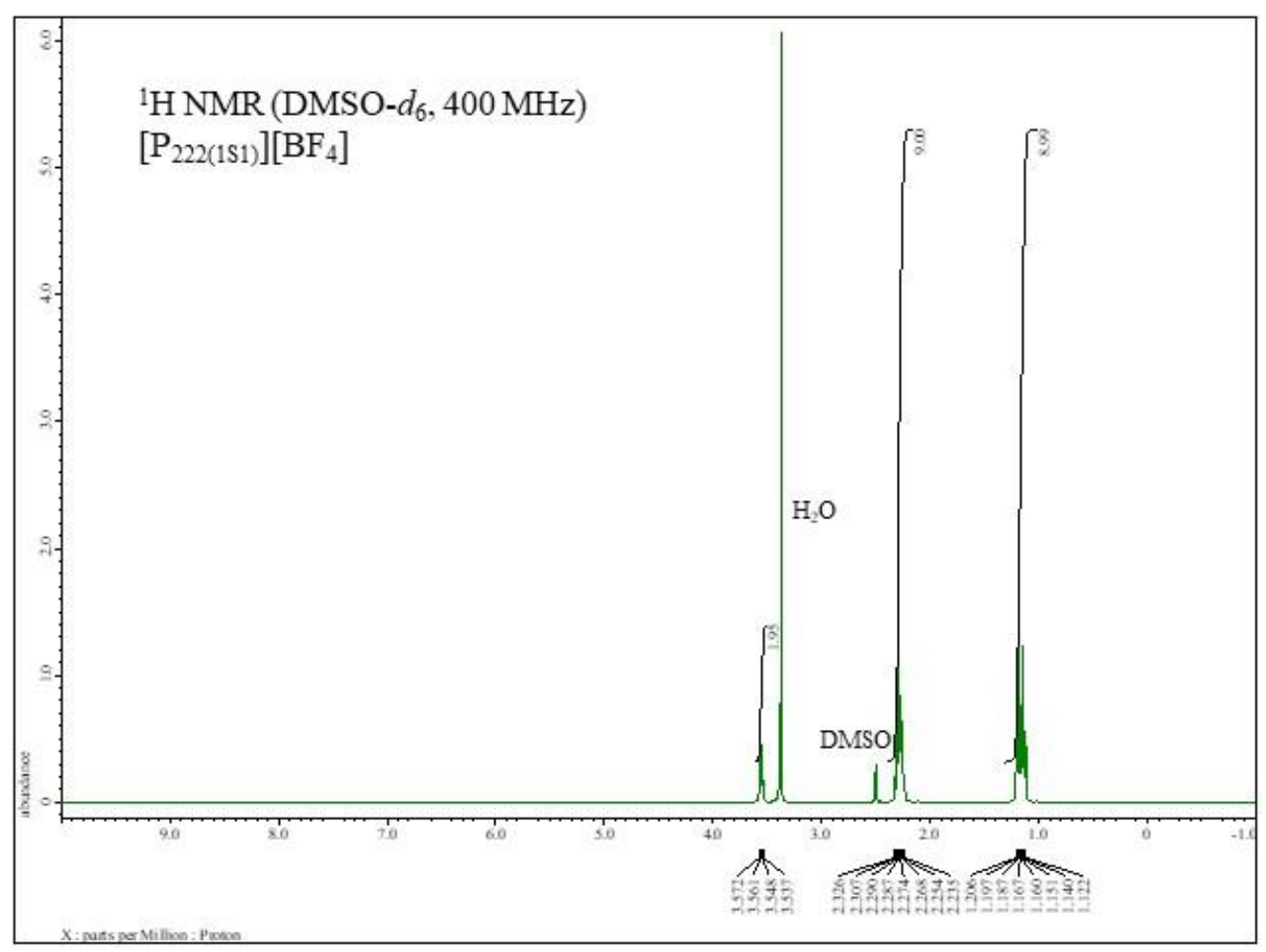

Figure $\mathrm{S} 13 . \quad{ }^{1} \mathrm{H}$ NMR spectrum for $\left[\mathrm{P}_{222(1 \mathrm{~S} 1)}\right]\left[\mathrm{BF}_{4}\right]$.

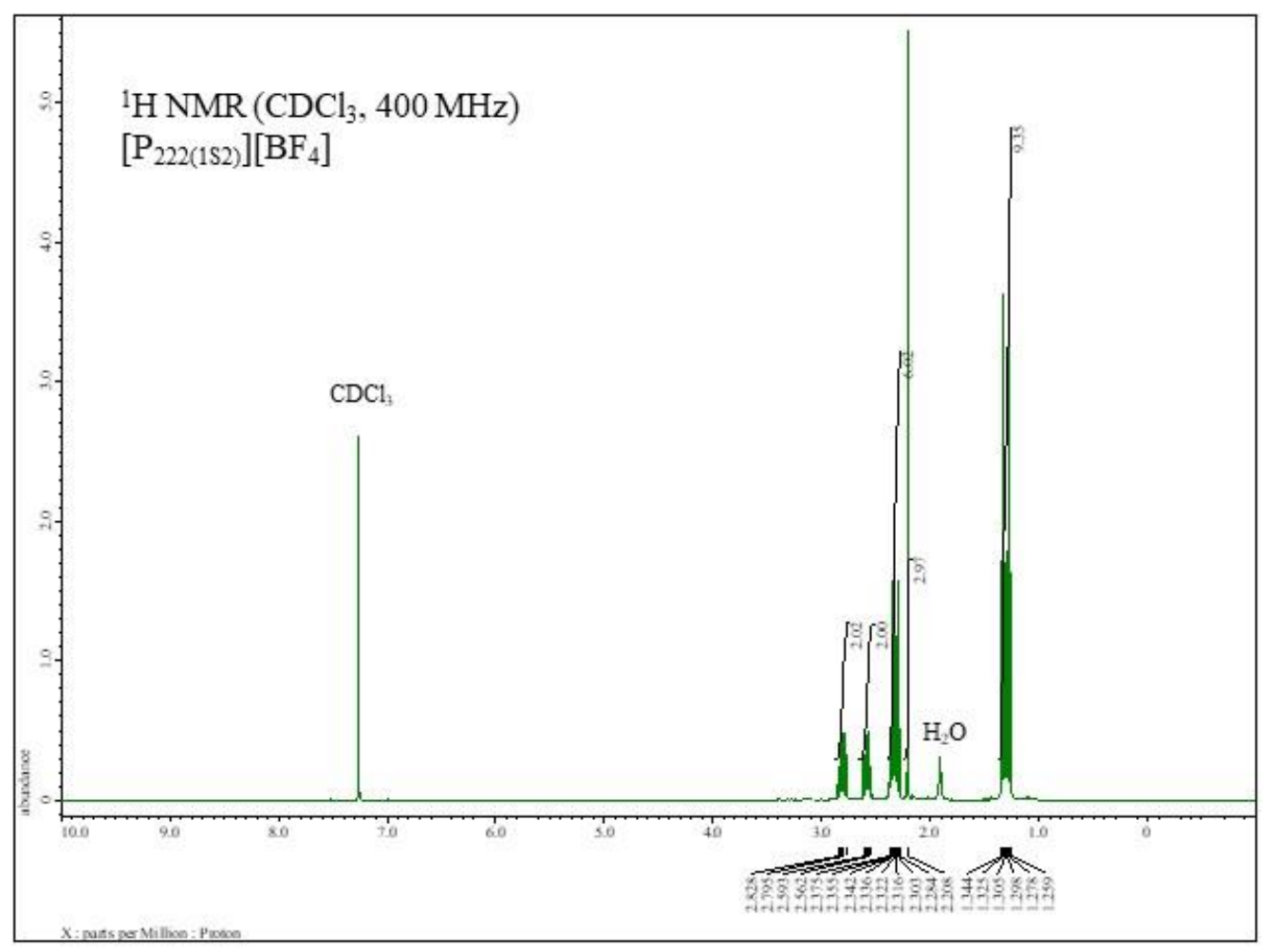

Figure $\mathrm{S} 14 . \quad{ }^{1} \mathrm{H}$ NMR spectrum for $\left[\mathrm{P}_{222(1 \mathrm{~S} 2)}\right]\left[\mathrm{BF}_{4}\right]$. 


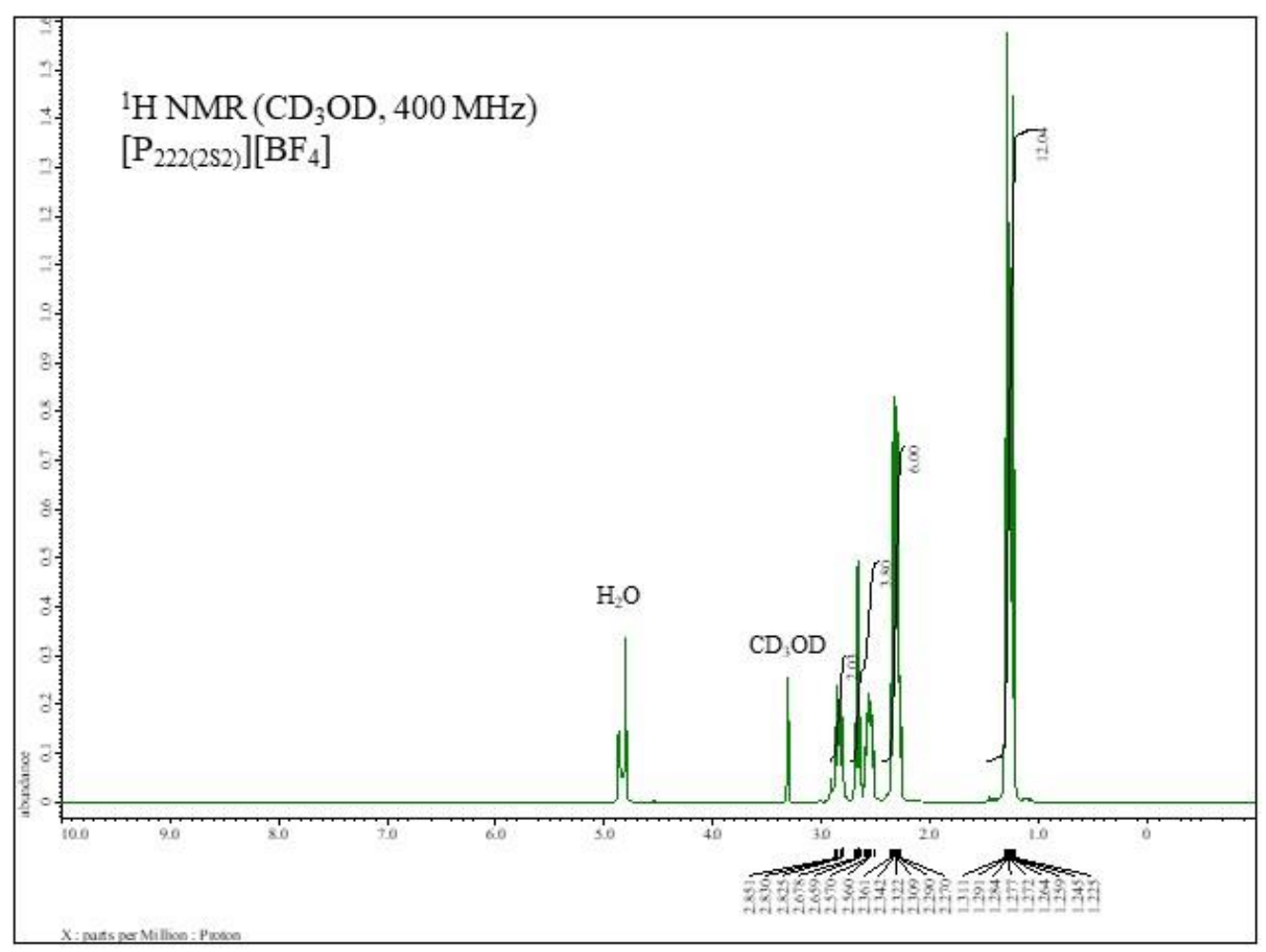

Figure $\mathrm{S} 15 . \quad{ }^{1} \mathrm{H}$ NMR spectrum for $\left[\mathrm{P}_{222(2 \mathrm{~S} 2)}\right]\left[\mathrm{BF}_{4}\right]$.

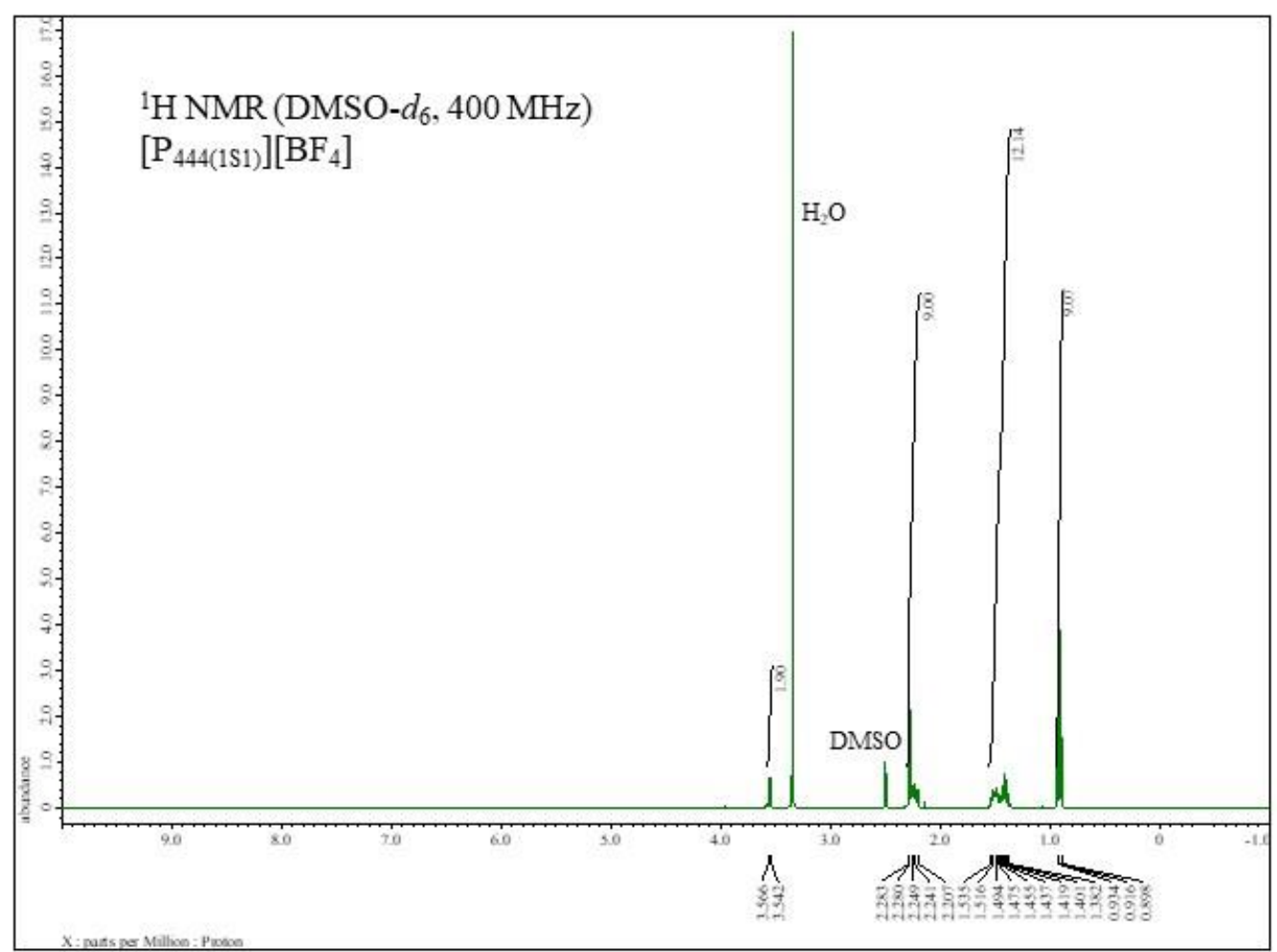

Figure S16. ${ }^{1} \mathrm{H}$ NMR spectrum for $\left[\mathrm{P}_{444(1 \mathrm{~S} 1)}\right]\left[\mathrm{BF}_{4}\right]$. 


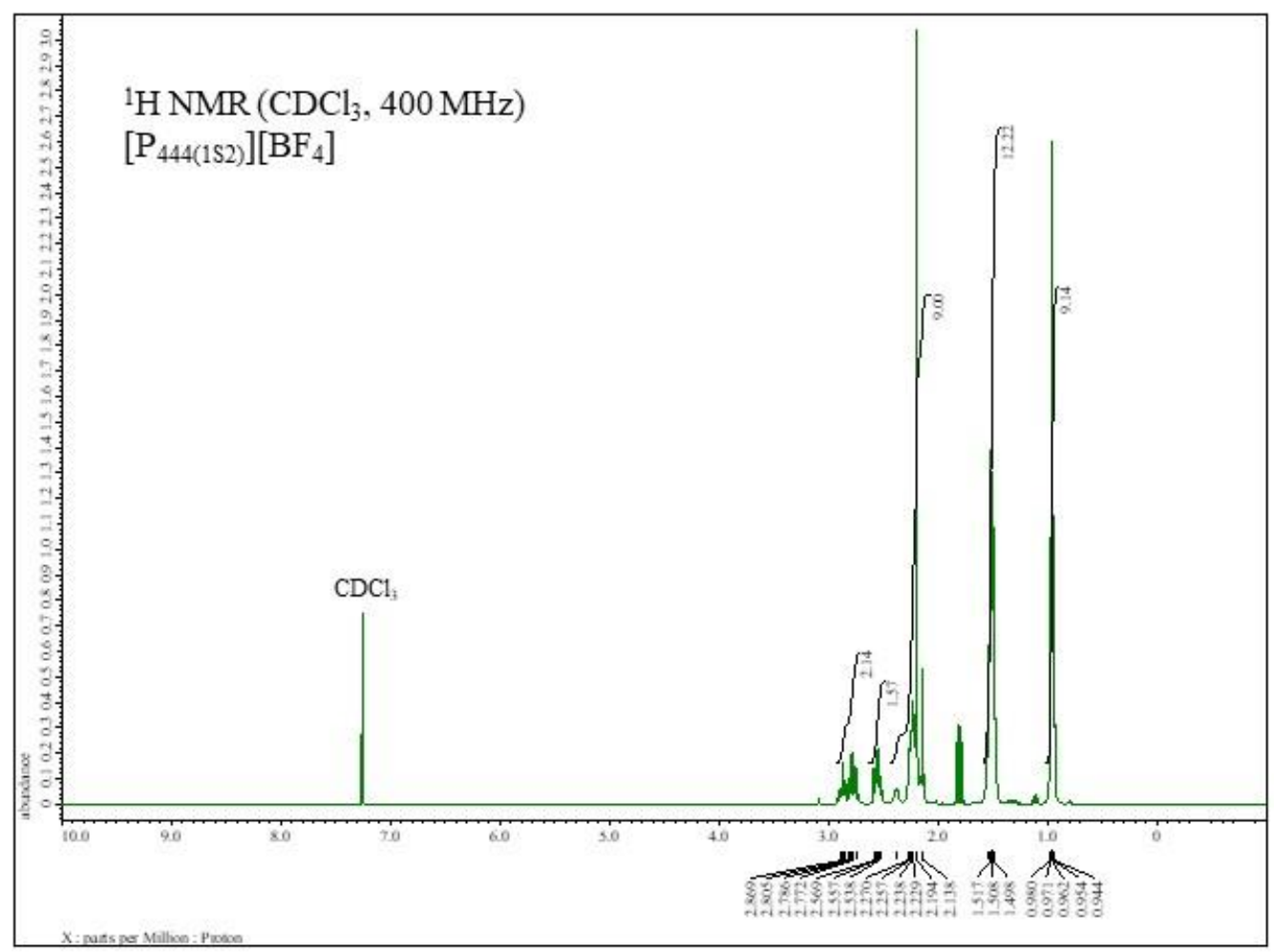

Figure $\mathrm{S} 17 . \quad{ }^{1} \mathrm{H}$ NMR spectrum for $\left[\mathrm{P}_{444(1 \mathrm{~S} 2)}\right]\left[\mathrm{BF}_{4}\right]$.

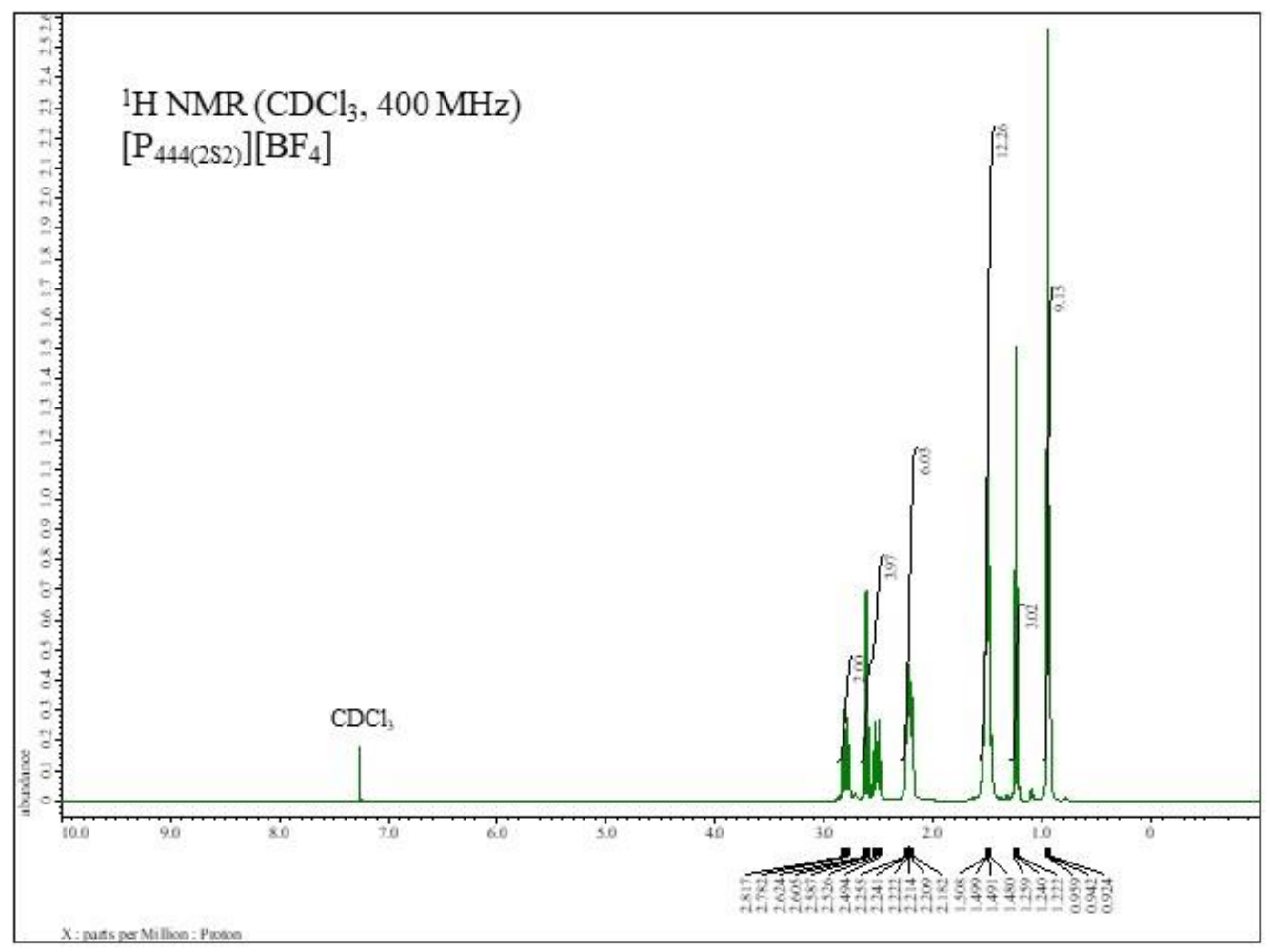

Figure $\mathrm{S} 18 . \quad{ }^{1} \mathrm{H}$ NMR spectrum for $\left[\mathrm{P}_{444(2 \mathrm{~S} 2)}\right]\left[\mathrm{BF}_{4}\right]$. 